\title{
Review on porous nanomaterials for adsorption and photocatalytic conversion of $\mathrm{CO}_{2}$
}

\author{
Yajuan Ma, Zemei Wang, Xiaofeng Xu, Jingyu Wang * \\ Key Laboratory of Material Chemistry for Energy Conversion and Storage (Ministry of Education), School of Chemistry and Chemical Engineering, \\ Huazhong University of Science and Technology, Wuhan 430074, Hubei, China
}

\section{A R T I C L E I N F O}

\section{Article history:}

Received 11 October 2017

Accepted 31 October 2017

Published 5 December 2017

\section{Keywords:}

Porous material

Composite nanostructure

$\mathrm{CO}_{2}$ adsorption

Photocatalysis

$\mathrm{CO}_{2}$ conversion

\begin{abstract}
A B S T R A C T
Photocatalytic conversion of "greenhouse gas" $\mathrm{CO}_{2}$ is considered to be one of the most effective ways to alleviate current energy and environmental problems without additional energy consumption and pollutant emission. The performance of many traditional semiconductor photocatalysts is not efficient enough to satisfy the requirements of practical applications because of their limited specific surface area and low $\mathrm{CO}_{2}$ adsorption capacity. Therefore, the exploration of photocatalysts with high $\mathrm{CO}_{2}$ uptake is significant in the field of $\mathrm{CO}_{2}$ conversion. Recently the porous materials appeared to be a kind of superior candidate for enriching the $\mathrm{CO}_{2}$ molecules on the surface of photocatalysts for catalytic conversion. This paper first summarizes the advances in the development of nanoporous adsorbents for $\mathrm{CO}_{2}$ capture. Three main classes of porous materials are considered: inorganic porous materials, metal organic frameworks, and microporous organic polymers. Based on systematic research on $\mathrm{CO}_{2}$ uptake, we then highlight the recent progress in these porous-material-based photocatalysts for $\mathrm{CO}_{2}$ conversion. Benefiting from the improved $\mathrm{CO}_{2}$ uptake capacity, the porous-material-based photocatalysts exhibited remarkably enhanced efficiency in the reduction of $\mathrm{CO}_{2}$ to chemical fuels, such as $\mathrm{CO}, \mathrm{CH}_{4}$, and $\mathrm{CH}_{3} \mathrm{OH}$. Based on reported recent achievements, we predict a trend of development in multifunctional materials with both high adsorption capability and photocatalytic performance for $\mathrm{CO}_{2}$ utilization.
\end{abstract}

(C) 2017, Dalian Institute of Chemical Physics, Chinese Academy of Sciences. Published by Elsevier B.V. All rights reserved.

\section{Introduction}

Today, the increasing emission amounts of the "greenhouse gas" $\mathrm{CO}_{2}$ in the atmosphere by the excessive consumption of fossil fuels (Fig. 1) have given rise to two serious problems: a shortage of usable energy and global climate warming [1]. Making full use of this natural $\mathrm{CO}_{2}$-rich source by fixing and transforming it cannot only alleviate the greenhouse effect but also generate chemical fuels for carbon resource recycling. In addition to the capture and storage technique, $\mathrm{CO}_{2}$ conversion appears to be an attractive solution to the energy and envi- ronmental problems [2]. There are many $\mathrm{CO}_{2}$ conversion methods, such as plasma reduction [3], biotransformation [4], thermal-assisted catalysis [5], electrocatalytic reduction, and photocatalytic reduction [6-8]. However, because $\mathrm{CO}_{2}$ is an inert and thermodynamically stable molecule, which requires high energy input for the activation and conversion processes, most $\mathrm{CO}_{2}$ conversion techniques are potentially energy consuming.

Photocatalysis emerged as an economical technology for $\mathrm{CO}_{2}$ conversion because it utilizes solar energy to trigger the photochemical reduction of $\mathrm{CO}_{2}$ to produce hydrocarbon fuels.

\footnotetext{
* Corresponding author. Tel: +86-27-87543032; Fax: +86-27-87543632; E-mail: jingyu.wang@163.com This work was supported by the National Natural Science Foundation of China $(21771070,21571071)$. DOI: 10.1016/S1872-2067(17)62955-3 | http://www.sciencedirect.com/science/journal/18722067 | Chin. J. Catal., Vol. 38, No. 12, December 2017
} 


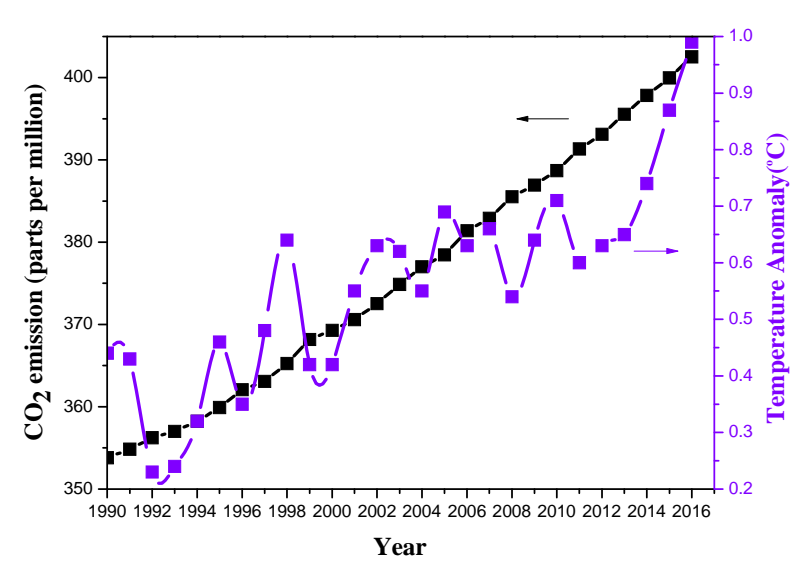

Fig. 1. The changes of annual $\mathrm{CO}_{2}$ emission and global mean surface temperature from 1990 to 2016 [1].

Compared with other methods, the photocatalytic conversion of $\mathrm{CO}_{2}$ can be performed under mild temperature and pressure [9-11]. Although the application prospect in this area is very broad, the current efficiency of photocatalysts toward $\mathrm{CO}_{2}$ adsorption and conversion remains very low, which is the biggest obstacle for the transformation of carbonaceous resources. Therefore, the design and synthesis of high-performance photocatalysts is the key to this technology. The performance of many traditional semiconductor photocatalysts is not efficient enough to satisfy the requirements for their practical applications because of their limited specific surface area and low $\mathrm{CO}_{2}$ adsorption capacity [12-14]. For the specificity of the $\mathrm{CO}_{2}$ reduction reaction, an ideal photocatalytic material should possess strong $\mathrm{CO}_{2}$ adsorption capacity and high catalytic activity. Porous materials have attracted extensive research interest in the $\mathrm{CO}_{2}$ adsorption field because of their well-developed pore structure and high specific surface area [15]. The advantages of different porous materials in $\mathrm{CO}_{2}$ adsorption are summarized in Table 1. Upon introducing porous materials with high $\mathrm{CO}_{2}$ uptake into the photocatalytic system, the $\mathrm{CO}_{2}$ molecules can be adsorbed and enriched on the surface of the photocatalyst for catalytic conversion. In this regard, the development of multifunctional materials exhibiting both high $\mathrm{CO}_{2}$ uptake and photocatalytic performance is one of the most promising directions for the photocatalytic conversion of $\mathrm{CO}_{2}$.

\section{Porous materials for $\mathrm{CO}_{2}$ adsorption}

The methods of $\mathrm{CO}_{2}$ capture include physical adsorption, chemical adsorption, membrane separation, among others. Because of van der Waals forces, the adsorbent surface is covered by a single layer or multi-layer of the molecular adsorbent (Fig. 2(a)), which is characterized as physical adsorption. Chemical adsorption is a process involving the exchange and transfer of valence electrons between the molecular adsorbent and atoms (molecules) on the surface of the adsorbent to form a chemical bond (Fig. 2(b)). Fig. 2(c) presents a schematic diagram of a membrane-separation process [32]. In general, the feed stream is provided at the high-pressure side, whereas the permeate stream flows out at the low-pressure side with the retentate adsorbing on the membrane. In this work, we only focused on solid porous adsorbents for the physical adsorption of $\mathrm{CO}_{2}$ molecules. In addition, the microcosmic mechanism of the competitive adsorption behavior between $\mathrm{CO}_{2}$ and $\mathrm{CH}_{4}$ on the surface of carbon models was investigated using density functional theory (DFT) calculations [33]. The results indicated that the adsorption of the injected $\mathrm{CO}_{2}$ promoted the desorption of $\mathrm{CH}_{4}$, thus visually proving the effectiveness of $\mathrm{CO}_{2}$-ECMB (enhanced coal-bed methane), which was beneficial in trapping $\mathrm{CO}_{2}$.

The adsorption method, which relies mainly on porous materials with a high specific surface area for $\mathrm{CO}_{2}$ adsorption, has been the subject of extensive research and application in the field of $\mathrm{CO}_{2}$ capture. The physical adsorption method is based on the intermolecular attraction between the target molecules and the surface active sites of the porous solid adsorbent. A series of porous solid adsorbents for physical adsorption emerged in the fields of $\mathrm{CO}_{2}$ adsorption and separation. There are three typical categories of adsorbent porous materials: inorganic porous materials (IPMs), metal organic frameworks (MOFs), and microporous organic polymer (MOPs). The $\mathrm{CO}_{2}$ adsorption capacity and selectivity as well as the resistance to water vapor mostly depend on the physical characteristics and surface chemical properties of the porous materials. The latest research progress in the area of high-performance porous materials for $\mathrm{CO}_{2}$ adsorption is reviewed with reference to the material structure parameters and performance.

Table 1

Advantages and disadvantages of adsorbent porous materials.

\begin{tabular}{|c|c|c|c|}
\hline Solid adsorbent & Advantages & Disadvantages & Ref. \\
\hline Porous carbon & $\begin{array}{l}\text { Various precursors; low cost; light weight; acid and } \\
\text { alkali resistance; high thermal-/photo-stability }\end{array}$ & $\begin{array}{l}\text { Poor selectivity; poor water resistance; } \\
\text { unsuitable for high pressure adsorption }\end{array}$ & [16-18] \\
\hline Molecular sieves & $\begin{array}{l}\text { Uniform pore size; definite skeleton structure; } \\
\text { high porosity; high thermal-/photo-stability }\end{array}$ & $\begin{array}{c}\text { Poor water resistance; unsuitable for high pressure } \\
\text { adsorption; instability under acid or } \\
\text { alkali condition }\end{array}$ & {$[19,20]$} \\
\hline Mesoporous silicon & $\begin{array}{l}\text { Well-developed pore structure; adjustable pore size; } \\
\text { high thermal-/photo-stability }\end{array}$ & $\begin{array}{l}\text { Poor selectivity; unsuitable for high pressure adsorp- } \\
\text { tion; instability under acid or alkali condition }\end{array}$ & [21-24] \\
\hline MOFs & $\begin{array}{c}\text { Metal-containing active sites; large specific surface area; } \\
\text { adjustable micropore size; artificially directional } \\
\text { synthesis; designable surface property }\end{array}$ & $\begin{array}{c}\text { Complicated synthesis; high cost; low adsorption } \\
\text { capacity under low pressure; instability under } \\
\text { acid or alkali condition }\end{array}$ & [25-28] \\
\hline MOPs & $\begin{array}{l}\text { Small density; large specific surface area; adjustable } \\
\text { micropore size; artificially directional synthesis; designable } \\
\text { surface property; a certain acid and alkali resistance }\end{array}$ & $\begin{array}{l}\text { Low adsorption capacity under low pressure; } \\
\text { poor thermal-/photo-instability }\end{array}$ & {$[29,30]$} \\
\hline
\end{tabular}


(a)

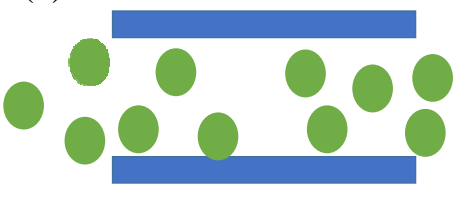

(c)

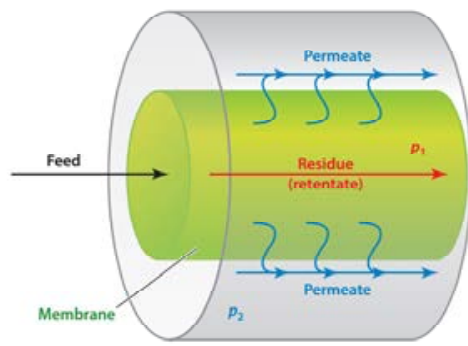

(b)
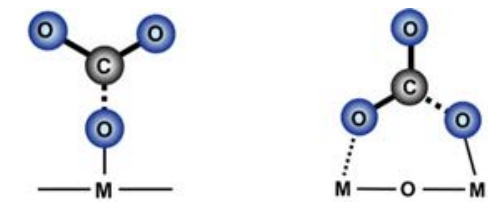

Monodentated Carbonates

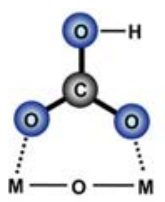

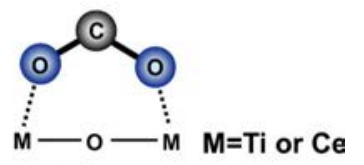

Fig. 2. (a) Physical adsorption and diffusion in nanoporous materials; (b) Schematic diagram of surface species for the chemical adsorption of $\mathrm{CO}_{2}$ on $\mathrm{TiO}_{2}$ and/or $\mathrm{CeO}_{2}$ surfaces (Copyright permission from Elsevier, Ref. [31]); (c) Scheme of simplified membrane gas-separation system such that P1 is feed (or retentate) pressure and P2 is permeate pressure (Copyright permission from Annual Reviews, Ref. [32]).

\subsection{Inorganic porous materials}

\subsubsection{Porous carbon materials}

Carbon materials, including activated carbon, carbon fiber, and carbon nanotubes, are excellent adsorbent materials. Their high specific surface area and well-developed porous structures enable these materials to be applied in complex environments (such as acids, alkalis, and water vapor) and play an important role in the field of gas adsorption/separation. To date, many types of porous carbons have been well commercialized in gas adsorption/separation systems, including for $\mathrm{CO}_{2}$ capture. For example, Silvestre-Albero et al. [34] reported petroleum pitch super activated carbon (VR-5 and VR-93) prepared by a chemical activation method using $\mathrm{KOH}$ as an activating agent. At $25^{\circ} \mathrm{C}$ and 50 bar, the volume adsorption capacity can be as high as 380 and $500 \mathrm{~cm}^{3} / \mathrm{cm}^{3}$, respectively. Therefore, the adsorption capacity of $\mathrm{CO}_{2}$ and other gases on this type of material under high-pressure conditions is very large. Shen et al. [35] prepared a series of porous carbon fibers using a pre-oxidation-chemical activation method with carbon fiber as the raw material. The $\mathrm{CO}_{2}$ adsorption test indicated that the adsorption capacity was only $4.4 \mathrm{mmol} / \mathrm{g}$ at $25^{\circ} \mathrm{C}$ and 1 bar. Therefore, the primary problem is how to improve the low partial pressure adsorption capacity and separation selectivity of this material toward $\mathrm{CO}_{2} / \mathrm{N}_{2}$.

To improve the low-pressure adsorption capacity and selectivity of the activated carbon materials, the researchers introduced nitrogen-containing groups to enhance the affinity for $\mathrm{CO}_{2}$ based on the molecular structure of $\mathrm{CO}_{2}$ (electron distribution, polarity) to improve the adsorption capacity and selectivity under low-partial-pressure conditions. It is reported that polyethylenimine (PEI)-derived activated carbon having various nitrogen functional groups and rich nitrogen content possessed typical microporosity with a high specific surface area. The $\mathrm{CO}_{2}$ uptake at 1 bar was $4.9-5.7 \mathrm{mmol} / \mathrm{g}$ at $0{ }^{\circ} \mathrm{C}$ and $2.9-3.7$ $\mathrm{mmol} / \mathrm{g}$ at $25{ }^{\circ} \mathrm{C}$. The PEI-derived carbons also exhibited good stability during multi-cycle adsorption-desorption tests and a high selectivity of $\mathrm{CO}_{2}$ over $\mathrm{N}_{2}$ at $25^{\circ} \mathrm{C}[36]$.

\subsubsection{Molecular sieves}

Both natural and synthetic molecular sieves such as zeolites are among the most widely investigated adsorbents for $\mathrm{CO}_{2}$ adsorption [37]. The adsorption of $\mathrm{CO}_{2}$ on molecular sieves is characterized as physical adsorption. The adsorption capacity decreases rapidly with increasing temperature. In addition, the zeolite adsorbent, which has strong water absorption and low gas selectivity properties, is particularly sensitive to water vapor. Thus, unmodified zeolites are only suitable for anhydrous environments, which limits their industrial application.

With the aim of individuating adsorbing materials with better performance, considerable attention has been paid to the effect of surface modifications on increasing the $\mathrm{CO}_{2}$ adsorption capacity. The adsorption of $\mathrm{CO}_{2}$ on the zeolite after modification changed from physical adsorption to chemical adsorption, which improved not only the adsorption capacity of $\mathrm{CO}_{2}$ but also the water resistance and the selectivity against $\mathrm{N}_{2}$. Because amine-based chemical absorption is one of the most commonly used techniques for $\mathrm{CO}_{2}$ removal in industry, several studies have explored the integration of organic amines into porous supports for $\mathrm{CO}_{2}$ adsorption. The functionalization of zeolites with amines was reported by Su et al. [38], who used a Y-type zeolite with a Si/Al molar ratio of 60 (Y60) modified with tetraethylenepentamine (TEPA). They noticed that the surface characteristics of Y60 were significantly altered after TEPA grafting, leading to enhanced adsorption capacity toward $\mathrm{CO}_{2}$, especially in the presence of water vapor.

\subsubsection{Mesoporous silicon}

Mesoporous silicon has a large specific surface area and a uniform pore size distribution in the range of $2-10 \mathrm{~nm}$, which enable its broad application in the fields of adsorption, separation, and catalysis. Currently, the mesoporous silicon materials mainly used for $\mathrm{CO}_{2}$ adsorption are M41S series [21] and SBA- $x$ series [22]. The most common types of mesoporous silica are MCM-41 [23] and SBA-15 [24]. Unfortunately, pure silica surfaces do not provide strong adsorption sites for $\mathrm{CO}_{2}$ because the residual hydroxyl groups are attached to the silica surface 
after the template removal step. Thus, the mesoporous silicon fails to induce significant interactions with $\mathrm{CO}_{2}$, and further specific adsorption sites are missing.

Surface modification is an interesting strategy to modify the surface properties and further increase the gas adsorption interaction. Harlick et al. [39,40] prepared a triethylamine-modified mesoporous silica molecular sieve TRI-PE-MCM-41, and the effects of amine grafting and water content on the $\mathrm{CO}_{2}$ adsorption were investigated. The results showed that the adsorption capacity and rate of TRI-PE-MCM-41 were determined by the amount of amine grafting and water content. The adsorption capacity of TRI-PE-MCM-41 for $\mathrm{CO}_{2}$ reached 2.65 $\mathrm{mmol} / \mathrm{g}$ at $25^{\circ} \mathrm{C}$ and $0.1 \mathrm{MPa}$. Table 2 summarizes the results of studies on the amino-functionalized ordered mesoporous silicates for $\mathrm{CO}_{2}$ adsorption and separation. The enhancement in $\mathrm{CO}_{2}$ adsorption by amine functionalization relies on the acid-base chemical interaction between $\mathrm{CO}_{2}$ and amine groups [41], leading to the formation of carbamate or bicarbonate species. Under dry conditions, the reaction between $\mathrm{CO}_{2}$ molecules and amine groups leads to the formation of carbamates. As another peculiarity, the presence of water vapor usually decreases their adsorption capacity; therefore, further development of amino-functionalized mesoporous silicates with water resistance is expected in the future.

\subsection{Metal organic frameworks}

MOFs known as coordination polymers are a relatively new class of porous materials with high diversity for application in gas separation, storage, and catalysis $[25,26]$. With a high specific surface area, the large amount of space inside and outside the channels makes the $\mathrm{CO}_{2}$ adsorption capacity of MOFs far greater than that of the IPMs described earlier [52]. In 2005, Yaghi et al. [53] reported the adsorption capacity of $\mathrm{CO}_{2}$ for a series of MOFs. MOF-177 had a volume capacity of $320 \mathrm{~cm}^{3}$ (STP) $/ \mathrm{cm}^{3}$ and a mass capacity of $33.5 \mathrm{mmol} / \mathrm{g}$ at $25^{\circ} \mathrm{C}$ and 35 bar, which are 2.17 and 4.53 times that for the commercial molecular sieve 13X and 1.97 and 1.34 times that for the activated carbon Maxsorb. In 2008, the volume capacity and mass capac-

Table 2

Amino-functionalized ordered mesoporous silicates for $\mathrm{CO}_{2}$ adsorption.

\begin{tabular}{lccc}
\hline Mesophase & Functionalizing agent & $\begin{array}{c}\mathrm{CO}_{2} \text { adsorption } \\
\text { capacity } \\
(\mathrm{mol} / \mathrm{kg})\end{array}$ & Ref. \\
\hline MCM-41 & $N$ - $\beta$-(aminoethyl)- $\gamma$-aminopropyl & 2.20 & {$[42]$} \\
& dimethoxy methylsilane & & \\
& Tetraethylenepentamine & 5.39 & {$[43]$} \\
& (3-Aminopropyl)trimethoxysilane & 3.27 & {$[44]$} \\
PBA-15 & Polyethylenimine & 5.59 & {$[45]$} \\
& Tetraethylenepentamine & 3.93 & {$[46]$} \\
& Tetraethylene- & 3.70 & {$[47]$} \\
& pentamine/diethanolamine & & \\
& Aziridine-derived aminopolymers & 5.55 & {$[48]$} \\
& (3-Trimethoxysilylpropyl) & 2.41 & {$[49]$} \\
& diethylenetriamine & & \\
& Octa(3-aminophenyl) & 1.89 & {$[50]$} \\
$\quad$ octasilsesquioxane & & \\
& Tris(2-aminoethyl)amine & $1.59-1.82$ & {$[51]$} \\
\hline
\end{tabular}

ity of MIL-101 (Cr) prepared by Llewellyn et al. [54] were 390 $\mathrm{cm}^{3}$ (STP) $/ \mathrm{cm}^{3}$ and $40 \mathrm{mmol} / \mathrm{g}$ at $31^{\circ} \mathrm{C}$ and 50 bar, which was a new record for $\mathrm{CO}_{2}$ adsorption capacity for MOFs. In 2010, Yaghi et al. [55] prepared MOF-210 with ultra-high porosity, and the record value increased to $54.5 \mathrm{mmol} / \mathrm{g}$.

The current adsorption and separation technology is generally performed under moderate conditions; therefore, the $\mathrm{CO}_{2}$ adsorption of MOFs at room temperature and atmospheric pressure is of practical significance $[27,28]$. Table 3 lists the $\mathrm{CO}_{2}$ adsorption capacities of several types of MOF materials at room temperature and 1 bar, which reveals that the adsorption capacity of $\mathrm{CO}_{2}$ is closely related to factors such as the content of unsaturated metal and $-\mathrm{NH}_{2}$, which can interact strongly with $\mathrm{CO}_{2}$ gas. Yaghi et al. [56] reported that the $\mathrm{CO}_{2}$ adsorption capacity of Mg-MOF-74 with rich unsaturated $\mathrm{Mg}$ atoms reached as high as $8.48 \mathrm{~mol} / \mathrm{kg}$ at 1 bar. Therefore, Mg-MOF-74 was regarded as an ideal $\mathrm{CO}_{2}$ trapping material.

Amino modification has commonly been used as an effective way to improve the $\mathrm{CO}_{2}$ selectivity of adsorbent materials. An et al. [64] prepared Bio-Mg-11 by grafting organic amines on Co-based MOFs. At $0{ }^{\circ} \mathrm{C}$ and atmospheric pressure, the saturated adsorption capacity of $\mathrm{CO}_{2}$ was $6.0 \mathrm{mmol} / \mathrm{g}$ and the selectivity of $\mathrm{CO}_{2} / \mathrm{N}_{2}$ reached $75 \%$. Couck et al. [65] modified MIL-53 (Al) with organic amines to increase its $\mathrm{CO}_{2}$ adsorption capacity to $6.7 \mathrm{mmol} / \mathrm{g}$ with high selectivity of $\mathrm{CO}_{2} / \mathrm{CH}_{4}$.

In addition, MOFs are very sensitive to water vapor and impurities. To overcome these problems, researchers have improved their water resistance through modification [66-68]. For example, Cohen et al. [68] grafted long-chain alkyl groups onto IRMOF-3 to induce hydrophobicity. Li et al. [69] prepared anti-water vapor microporous amine-modified MOFs. At $25{ }^{\circ} \mathrm{C}$ and $1 \mathrm{bar}$, the adsorption capacity of $\mathrm{CO}_{2}$ was $2.45 \mathrm{mmol} / \mathrm{g}$, whereas that of $\mathrm{CH}_{4}$ was only $2.68 \times 10^{-5} \mathrm{mmol} / \mathrm{g}$. The large separation coefficient (approximately $9.1 \times 10^{4}$ ) in this work represented an important step in the synthesis of MOFs.

\subsection{Microporous organic polymers}

Compared with MOFs and inorganic porous materials, porous organic polymers can regulate gas adsorption performance over a wide range through modification of the functional groups and chain lengths of the building molecules. Because most microporous organic polymers (MOPs) exhibit good chemical and thermal stability, they have potential applications

Table 3

MOFs with higher $\mathrm{CO}_{2}$ adsorption capacity under atmospheric pressure.

\begin{tabular}{|c|c|c|c|c|c|c|}
\hline \multirow{2}{*}{ MOF } & \multicolumn{2}{|c|}{ Surface aera $\left(\mathrm{m}^{2} / \mathrm{g}\right)$} & \multirow{2}{*}{$\begin{array}{c}\mathrm{CO}_{2} \text { uptake } \\
(\mathrm{mol} / \mathrm{kg})\end{array}$} & \multirow{2}{*}{$T /{ }^{\circ} \mathrm{C}$} & \multirow{2}{*}{$P /$ bar } & \multirow{2}{*}{ Ref. } \\
\hline & BET & Langmuir & & & & \\
\hline MOF-74(Mg) & 1495 & 1905 & 8.48 & 25 & 1 & [57] \\
\hline MOF-74(Co) & 957 & 1388 & 7.55 & 25 & 1 & [57] \\
\hline MOF-74(Ni) & 936 & 1356 & 7.15 & 25 & 1 & [57] \\
\hline bio-MOF-11 & - & - & 6.00 & 0 & 1 & {$[5$} \\
\hline MOF-74(Zn) & 816 & - & 5.54 & 23 & $1 \mathrm{~atm}$ & {$[5$} \\
\hline SIFSIX-2-Cu-i & 735 & 821 & 5.41 & 25 & 1 & {$[60$} \\
\hline CUK-1 & 310 & - & 3.48 & 25 & 760 torr & {$[6$} \\
\hline YO-MOF & - & 335 & 3.39 & 0 & 1 & {$[6$} \\
\hline SNU-M10 & - & - & 3.30 & 0 & 1 & {$[6$} \\
\hline
\end{tabular}


in gas storage, adsorption, separation, and heterogeneous catalysis.

For example, some covalent organic frameworks (COFs) can be repeatedly used and maintain their good $\mathrm{CO}_{2}$ capture performance even under moist conditions [29]; therefore, COFs have been proposed as an excellent candidate for $\mathrm{CO}_{2}$ capture. Since the first report on $\mathrm{CO}_{2}$ adsorption of COFs in 2009, great efforts have been made to improve their $\mathrm{CO}_{2}$ capture performance. A plot of low-pressure $\mathrm{CO}_{2}$ uptake versus pore diameters for the selected COFs at $0{ }^{\circ} \mathrm{C}$ and 1 bar is presented in Fig. 3 , showing that low-pressure $\mathrm{CO}_{2}$ capture capacity is closely associated with the pore width of COFs. COFs with micropore diameters smaller than $1 \mathrm{~nm}$ usually possess large $\mathrm{CO}_{2}$ uptake, and FCTF-1-600 with an ultra-micropore size of 0.46 nm exhibits the largest $\mathrm{CO}_{2}$ capacity as high as $125 \mathrm{~cm}^{3} / \mathrm{g}$. Thus, the construction of COFs with uniform micropores or ultra-micropores is favorable for the enhancement of the low-pressure $\mathrm{CO}_{2}$ uptake. COFs with polar groups on the pore wall display much higher $\mathrm{CO}_{2}$ capture capacity than those without polar groups, which can be attributed to the stronger interaction of the polar groups with $\mathrm{CO}_{2}$ molecules [30]. Another criterion to evaluate the performance of porous materials is $\mathrm{CO}_{2}$ capture in humid mixture gas. A breakthrough experiment was performed on FCTF-1 in a humid $\mathrm{CO}_{2} / \mathrm{N}_{2}$ (10:90) gas mixture at $25^{\circ} \mathrm{C}$ and 1 bar [70]. The FCTF-1 saturated by water vapor only displayed a $12 \%$ decrease in $\mathrm{CO}_{2}$ uptake and a small reduction in $\mathrm{CO}_{2} / \mathrm{N}_{2}$ selectivity (from $77 \%$ to $66 \%$ ) compared with those in dry gas. Thus, the hydrophobic ultra-micropores of COFs help to maintain the $\mathrm{CO}_{2}$ capture performance under humid conditions.

In addition to crystalline COFs, there are some MOPs with an amorphous organic skeleton. Compared with crystalline polymers, the preparation processes of amorphous MOPs are relatively facile and can be easily scaled up. Because of the cross-linked channels, amorphous MOPs possess ultra-high specific surface areas and therefore have large-scale application prospects. Many research groups [71-74] have made contributions to the field of amorphous porous polymers. Zhu et al. [75] prepared a porous polymer PAF-1 by substituting a C-C

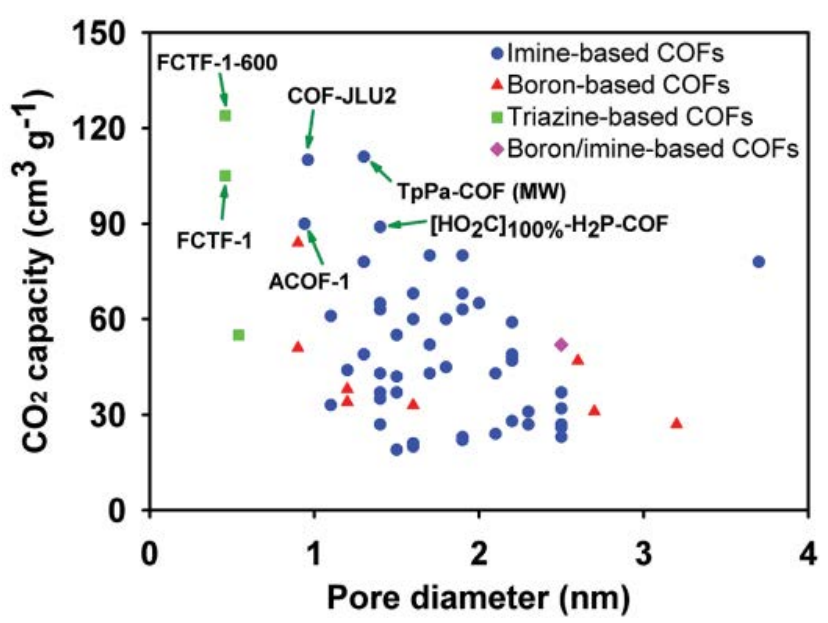

Fig. 3. Plot of low-pressure $\mathrm{CO}_{2}$ uptake against pore diameter for the selected COFs at $0{ }^{\circ} \mathrm{C}$ and 1 bar. Copyright permission from John Wiley and Sons, Ref. [30]. bond in the diamond structure with one (P1), two (P2), or three phenyl (P3) (Fig. 4). The specific surface area of these polymers was as high as $5600 \mathrm{~m}^{2} / \mathrm{g}$, and the $\mathrm{CO}_{2}$ adsorption reached $1300 \mathrm{mg} / \mathrm{g}$ at $25^{\circ} \mathrm{C}$ and $40 \mathrm{bar}$. This result was a milestone in the preparation of MOP materials and gas storage. Subsequently, Zhou et al. [73] adopted the same strategy to prepare a porous polymer PPN-4 with a specific surface area of 6461 $\mathrm{m}^{2} / \mathrm{g}$ and a $\mathrm{CO}_{2}$ adsorption capacity of $2121 \mathrm{mg} / \mathrm{g}$ at $22{ }^{\circ} \mathrm{C}$ and 50 bar.

Such polymers with ultra-high specific surface area have excellent high-pressure adsorption properties but low selectivity for low-pressure adsorption. The enhanced interaction between $\mathrm{CO}_{2}$ molecules and the polymer framework increased the low-pressure adsorption capacity and selectivity. For example, Zhou et al. [74] grafted sulfonic acid groups and lithium sulfide onto the surface of these porous polymers. The $\mathrm{CO}_{2}$ adsorption capacity of sulfonated grafted PPN-6-SO ${ }_{3} \mathrm{Li}$ at $22{ }^{\circ} \mathrm{C}$ was $3.7 \mathrm{mmol} / \mathrm{g}$ with selectivity of $\mathrm{CO}_{2} / \mathrm{N}_{2}$ as high as $155 / 1$, which was much higher than that of pristine PPN-6 (1.2 $\mathrm{mmol} / \mathrm{g})$.

\subsection{Other applications}

In addition to the special application in gas adsorption, the porous materials also showed potential for application in other fields. For example, the adsorption capacity and release of drugs could be easily controlled by adjusting the pore size and surface property of the porous materials. These porous materials can be used in biological fields as drug carriers for achieving drug release and improving the activity of drugs [76-78]. The porous carbons or MOFs/MOPs-derived carbons possessed high surface area, multi-dimensional channel structures, and electrical conductivity, which are favorable for rapid charge and mass transfer. These porous materials emerged as excellent electrode materials, supercapacitors, and anode materials a)
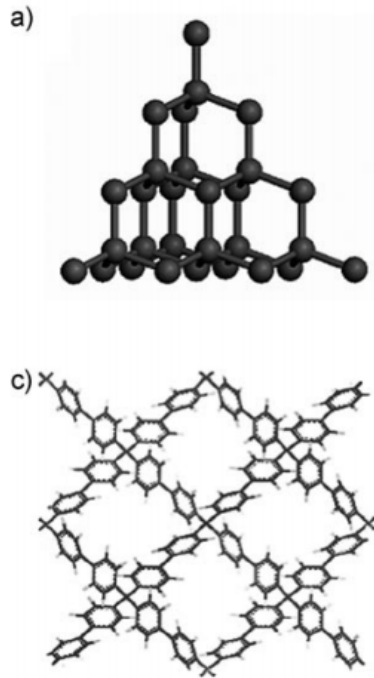

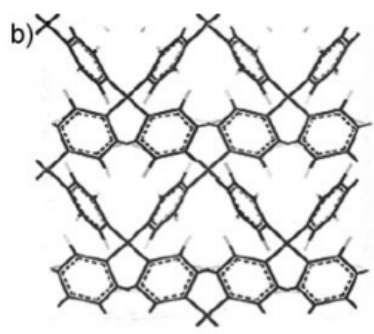

d)

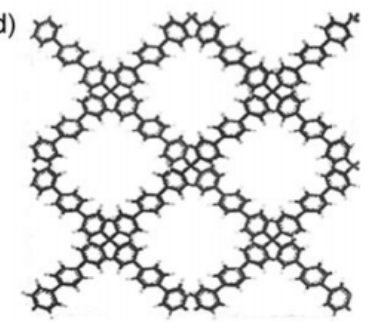

Fig. 4. (a) structure of diamond; (b) Structure model of P1; (c) Structure model of P2; (d) Structure model of P3. Copyright permission from John Wiley and Sons, Ref. [75]. 
for lithium-ion batteries [79-84]. Moreover, some of the porous materials enabled rapid adsorption of different targets, which can be regulated by the pore size. They showed potential for application in gas or liquid separation and pollutant elimination in environmental science fields [85-87].

\section{Porous-material-based photocatalysts for $\mathrm{CO}_{2}$ conversion}

Although the $\mathrm{CO}_{2}$ adsorption capacity has been improved by the modification of porous materials, the adsorption and separation technology cannot achieve the recycling of $\mathrm{CO}_{2}$ resources. $\mathrm{CO}_{2}$ recycling should include both adsorption and conversion. Adsorption is the basis of transformation, whereas the conversion of the adsorbed $\mathrm{CO}_{2}$ can essentially alleviate the energy and environment problems from $\mathrm{CO}_{2}$ emissions. Photocatalytic conversion of $\mathrm{CO}_{2}$ is considered one of the most economical conversion methods because it uses solar energy to trigger the $\mathrm{CO}_{2}$ reduction reaction (CRR) to produce chemical fuels (Fig. 5). As illustrated in Fig. 5(a), under light irradiation, the photogenerated electrons in the conduction band (CB) of semiconductors reduce $\mathrm{CO}_{2}$ through a sequence of reactions. The final oxidation state of the carbon atom in the products is determined by the number and rate of electrons transferred [88]. First-principles calculations on the thermodynamically feasible formaldehyde pathways was performed (Fig. 5(b)) [89]. There are two reaction paths: path $\mathrm{I}, \mathrm{CO}_{2} \rightarrow \mathrm{HCOOH} \rightarrow \mathrm{H}_{2} \mathrm{CO}$ $\rightarrow \mathrm{CH}_{3} \mathrm{OH} \rightarrow \mathrm{CH}_{4}$, and path II, $\mathrm{CO}_{2} \rightarrow \mathrm{CO} \rightarrow \mathrm{H}_{2} \mathrm{CO} \rightarrow \mathrm{CH}_{3} \mathrm{OH} \rightarrow \mathrm{CH}_{4}$. The rate-determining step of path $\mathrm{I}$ is photoreduction of $\mathrm{HCOOH}$ to $\mathrm{H}_{2} \mathrm{CO}$, whereas that of path II is photoreduction of $\mathrm{CO}_{2}$ to $\mathrm{CO}$. The photoreduction of $\mathrm{HCOOH}$ to $\mathrm{H}_{2} \mathrm{CO}$ has a kinetic barrier of $1.81 \mathrm{eV}$, which is much larger than that for the photoreduction of $\mathrm{CO}_{2}$ to $\mathrm{CO}(1.41 \mathrm{eV})$. It would be more efficient if $\mathrm{CO}$ instead of formic acid is the precursor of formaldehyde. It was concluded that the conversion efficiency depends on two processes, the $\mathrm{CO}_{2}$ adsorption and the effective electron transfer on the reaction sites of the photocatalysts. Currently, research on photocatalytic CRR has attracted widespread attention; however, the performance of many traditional semiconductor photocatalysts is not efficient enough to satisfy the re- quirements for their practical applications because of their limited specific surface area and low $\mathrm{CO}_{2}$ adsorption capacity. Upon introducing porous materials with high $\mathrm{CO}_{2}$ uptake into the photocatalytic system, the $\mathrm{CO}_{2}$ molecules can be adsorbed and enriched on the surface of the photocatalyst, presumably leading to remarkable enhancement of the CRR efficiency. Therefore, the construction of photocatalysts on porous materials is of great interest in the development of high-performance photocatalysts toward CRR application.

\subsection{IPM-based photocatalysts}

\subsubsection{Porous carbon-based photocatalysts}

The combination of porous carbon materials and photocatalysts will improve the catalytic CRR activity through the enlarged $\mathrm{CO}_{2}$ adsorption capacity and photothermal synergistic effect. Wang et al. [90] reported the synthesis of hybrid carbon@ $\mathrm{TiO}_{2}$ hollow spheres using a carbon nanosphere template (Fig. 6). The optimized carbon@ $\mathrm{TiO}_{2}$ composites exhibited enhanced photocatalytic activity for CRR compared with commercial $\mathrm{TiO}_{2}$ (P25). The photocatalytic $\mathrm{CH}_{4}$ production rate (4.2 $\mu$ mol g-1 $\mathrm{h}^{-1}$ ) was two times that of $\mathrm{TiO}_{2}$. Moreover, a large amount of $\mathrm{CH}_{3} \mathrm{OH}$ was produced $\left(9.1 \mu \mathrm{mol} \mathrm{g}-1 \mathrm{~h}^{-1}\right)$. The significantly improved photocatalytic activity resulted from the increased specific surface area $\left(110 \mathrm{~m}^{2} / \mathrm{g}\right)$ and $\mathrm{CO}_{2}$ uptake $(0.64$ $\mathrm{mmol} / \mathrm{g})$, together with the enhancement in light absorption and local photothermal effect by the carbon materials around the photocatalysts.

The proton reduction into $\mathrm{H}_{2}$ is the main competitive process of $\mathrm{CO}_{2}$ reduction, especially when using water as a reductant [91-95]. The $\mathrm{H}_{2}$ evolution consumed the amount of photogenerated electrons for CRR $[91,95]$. To improve the selectivity of photocatalytic CRR in the presence of water, wrapping a carbon layer outside the photocatalyst causes more protons from the water splitting to participate in the $\mathrm{CO}_{2}$ reduction, thereby facilitating the photocatalytic reduction of $\mathrm{CO}_{2}$ to $\mathrm{CO}$ and $\mathrm{CH}_{4}$. Pan et al. [96] reported that the use of $\mathrm{In}_{2} \mathrm{O}_{3}$ nanobelts coated with a 5-nm-thick carbon layer $\left(\mathrm{C}-\mathrm{In}_{2} \mathrm{O}_{3}\right)$ resulted in enhanced photocatalytic reduction of $\mathrm{CO}_{2}$ with $\mathrm{CO}$ and $\mathrm{CH}_{4}$ evolution rates of 126.6 and $27.9 \mu \mathrm{mol} / \mathrm{h}$, respectively. The $\mathrm{CO}_{2}$ (a)

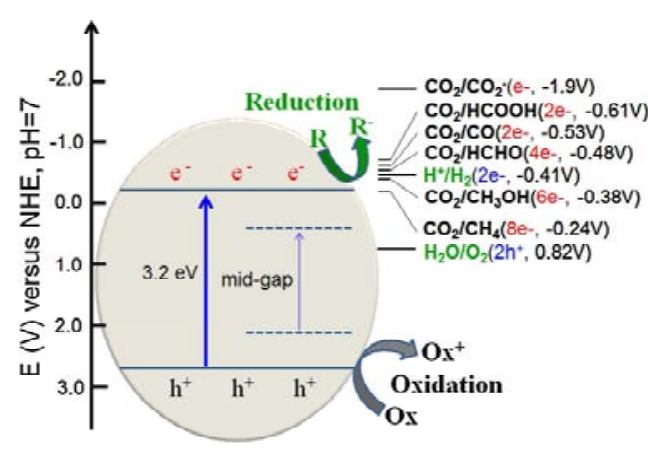

(b)

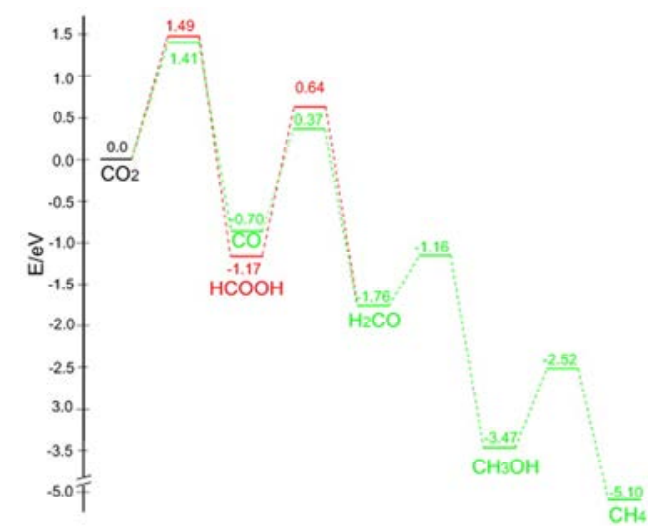

Fig. 5. (a) Schematic energy diagram for water reduction/oxidation and $\mathrm{CO}_{2}$ reduction (Copyright permission from Elsevier, Ref. [88]); (b) Full potential energy surfaces for the photoreduction of $\mathrm{CO}_{2}$ to $\mathrm{CH}_{4}$ (Copyright permission from American Chemical Society, Ref. [89]). 
(a)

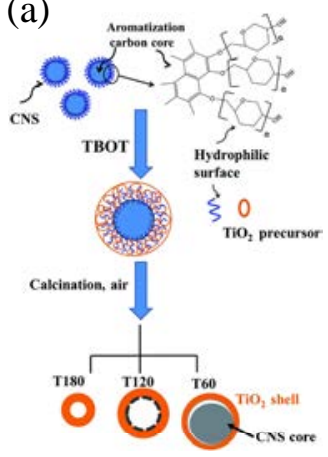

(b)

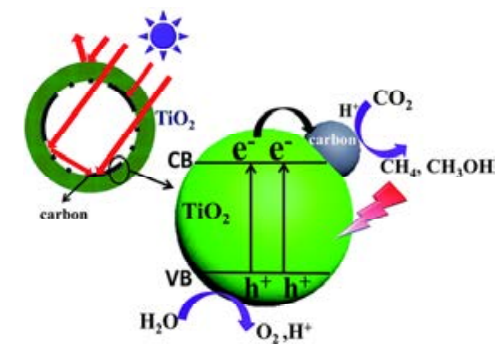

Fig. 6. (a) Illustration of the formation mechanism; (b) Photoexcitation process for the carbon@ $\mathrm{TiO}_{2}$ composite photocatalyst with hollow structure. Copyright permission from Royal Society of Chemistry, Ref. [90].

adsorption capacity on the $\mathrm{C}$ - $\operatorname{In}_{2} \mathrm{O}_{3}$-based catalyst reached a maximum value $(2.2 \mathrm{mmol} / \mathrm{g}$ ) that was larger than those on the pure $\mathrm{In}_{2} \mathrm{O}_{3}$ and pure carbon. The improved $\mathrm{CO}_{2}$ chemisorption increased the probability of proton capture by the $\mathrm{CO}_{2}{ }^{-}$and promoted the photocatalytic reduction of $\mathrm{CO}_{2}$ to $\mathrm{CO}$ and $\mathrm{CH}_{4}$.

In addition, it was proved that the CRR performance can be greatly enhanced by using carbon-based two-dimensional (2D) layered materials, namely graphitic carbon nitride $\left(\mathrm{g}-\mathrm{C}_{3} \mathrm{~N}_{4}\right)$ and graphene because of their excellent electronic and physicochemical properties [97]. Li et al. [98] prepared a g- $\mathrm{C}_{3} \mathrm{~N}_{4}$-loaded $\mathrm{Bi}_{2} \mathrm{WO}_{6}$ photocatalyst, which exhibited 22 and 6.4 times higher $\mathrm{CO}$ production rates than pure g- $\mathrm{C}_{3} \mathrm{~N}_{4}$ and $\mathrm{Bi}_{2} \mathrm{WO}_{6}$, respectively. Yu et al. [99] reported that the use of the graphene/CdS nanorod composite resulted in a photocatalytic production rate of $\mathrm{CH}_{4}$ of $2.51 \mu \mathrm{mol} \mathrm{h}{ }^{-1} \mathrm{~g}^{-1}$, which was 10 times higher than that achieved on pure CdS. It is known that the $2 \mathrm{D} \pi$-conjugated structure can participate in $\pi-\pi$ interactions with $\mathrm{CO}_{2}$ molecules, which also contain delocalized $\pi$-conjugated electrons. In this way, the $\mathrm{CO}_{2}$ adsorption capacity can be improved, which led to the enhanced CRR performance.

\subsubsection{Molecular-sieve-based photocatalysts}

Molecular sieves such as zeolite can provide reaction sites within micropores, resulting in a high removal efficiency of volatile organic compounds [100]; hence, they enable certain selectivity for accessing reactants. The pore size effect is an important factor in determining the photocatalytic performance of molecular-sieve-based photocatalysts. Yuichii et al. [101] prepared Ti-MCM-41 and Ti-MCM-48 by loading $\mathrm{TiO}_{2}$ onto porous zeolite via a hydrothermal method. In the reaction with $\mathrm{CO}_{2}$ and $\mathrm{H}_{2} \mathrm{O}$ under a $55^{\circ} \mathrm{C}$ gas phase, Ti-MCM-48 exhibited higher catalytic activity and selectivity to $\mathrm{CH}_{3} \mathrm{OH}$ because of its large pore size and three-dimensional channel structure. The introduction of molecular sieve supports has an important effect on the crystal structure of $\mathrm{TiO}_{2}$; therefore, the selectivity of the product can be altered. Hiromi et al. [102] prepared ex-TiO 2 /Y-zeolite, imp- $\mathrm{TiO}_{2} /$ Y-zeolite, and pure $\mathrm{TiO}_{2}$ catalysts via the ion-exchange and impregnation methods. The ex- $\mathrm{TiO}_{2} /$ Y-zeolite catalyst showed higher selectivity to $\mathrm{CH}_{3} \mathrm{OH}$. The former $\mathrm{TiO}_{2}$ had a tetrahedral structure, and the latter two catalysts had octahedral structures. $\mathrm{TiO}_{2}\left(\mathrm{Ti}^{3+}-\mathrm{O}^{-}\right)$with a tetrahedral structure was inclined to the formation of $\mathrm{CH}_{3} \mathrm{OH}$.

The reactivity and selectivity of the zeolite catalyst can be also determined from the hydrophilic and hydrophobic properties of the zeolites. Ikeue et al. [103] prepared two types of catalysts using two different SDAs: Ti-Beta(OH) and Ti-Beta(F). Ti-Beta(OH) exhibited a higher reactivity than Ti-Beta(F), and the selectivity for the formation of $\mathrm{CH}_{3} \mathrm{OH}$ on $\mathrm{Ti}-\mathrm{Beta}(\mathrm{F})$ was higher than that on Ti-Beta(OH). The hydrophilic Ti-Beta zeolite $(\mathrm{Ti}-\mathrm{Beta}(\mathrm{OH})$ ) exhibited a more dramatic increase in the coordination number than the hydrophobic Ti-Beta(F) zeolite. These results suggest that $\mathrm{CO}_{2}$ and $\mathrm{H}_{2} \mathrm{O}$ molecules can be adsorbed efficiently onto the highly dispersed tetrahedrally coordinated titanium oxide species.

\subsubsection{Mesoporous-silicon-based photocatalysts}

Heterogeneous photocatalysis has a high efficiency for the removal of highly toxic and non-biodegradable pollutants [104-106]. $\mathrm{TiO}_{2}$ supported on $\mathrm{SiO}_{2}$ and derivatives such as $\mathrm{SiO}_{2}$ films [107], MCM-41, and MCM-48 and SBA-15 [108,109] have been reported to exhibit high photocatalytic activity. Lin et al. [110] prepared DCQ- $\mathrm{TiO}_{2} / \mathrm{SBA}-15$, and the photocatalytic reduction of $\mathrm{CO}_{2}$ in water was conducted under visible-light illumination. The methanol yield over DCQ- $\mathrm{TiO}_{2} / \mathrm{SBA}-15$ was 0.44 $\mu \mathrm{mol} \mathrm{g} \mathrm{gat}^{-1} \mathrm{~h}^{-1}$, which was much higher than that of DCQ-P25 $\mathrm{TiO}_{2}\left(0.16 \mu \mathrm{mol} \mathrm{g} \mathrm{gat}^{-1} \mathrm{~h}^{-1}\right)$. The higher photocatalytic activity of DCQ-TiO $/$ SBA-15 was attributed to the larger amounts of adsorbed DCQ by the ordered nanochannels. Similarly, mesoporous- $\mathrm{SiO}_{2}$-supported catalysts are also suitable for gas-solid phase reactions. Li et al. [111] used a one-pot sol-gel method for the synthesis of $\mathrm{Cu} / \mathrm{TiO}_{2}-\mathrm{SiO}_{2}$ catalysts, and the photocatalysis was performed at a gas-solid interface. Pristine $\mathrm{TiO}_{2}$ had the lowest production rate, $8.1 \mu \mathrm{mol} \mathrm{gTiO}^{-1} \mathrm{~h}^{-1}$ for $\mathrm{CO}$. With the introduction of the mesoporous $\mathrm{SiO}_{2}$ support, the $\mathrm{CO}$ production increased to $22.7 \mu \mathrm{mol}_{\mathrm{TiO}^{-1}} \mathrm{~h}^{-1}$. This improvement may be due to the improved dispersion of $\mathrm{TiO}_{2}$ nanoparticles and enhanced adsorption of $\mathrm{CO}_{2}$ and $\mathrm{H}_{2} \mathrm{O}$ on the high surface area of the $\mathrm{SiO}_{2}$ substrate. Coupling mesoporous $\mathrm{SiO}_{2}$ with layered semiconductor materials exposed more active sites at the interface between $\mathrm{SiO}_{2}$ and the semiconductor, which is favorable for photocatalytic CRR. Li et al. [112] prepared lamellar $\mathrm{HNb}_{3} \mathrm{O}_{8}$ pillared with silica for $\mathrm{CO}_{2}$ photoreduction by $\mathrm{H}_{2} \mathrm{O}$ under ultraviolet (UV) light irradiation (Fig. 7). The yield of methane reached $2.9 \mu \mathrm{mol} \mathrm{g} \mathrm{cat}^{-1} \mathrm{~h}^{-1}$ over $\mathrm{SiO}_{2}-\mathrm{HNb}_{3} \mathrm{O}_{8}$, which is six times that over non-pillared $\mathrm{HNb}_{3} \mathrm{O}_{8}\left(0.47 \mu \mathrm{mol} \mathrm{gcat}^{-1} \mathrm{~h}^{-1}\right)$. The $\mathrm{SiO}_{2}$ pillared $\mathrm{HNb}_{3} \mathrm{O}_{8}$ sample had a notably expanded interlayer distance and much greater surface area than the nonpillared $\mathrm{HNb}_{3} \mathrm{O}_{8}$. Thus, the reaction active sites at the interlayer space of $\mathrm{SiO}_{2}-\mathrm{HNb}_{3} \mathrm{O}_{8}$ should have been more accessible to the substrates. In addition, the $\mathrm{SiO}_{2}-\mathrm{HNb}_{3} \mathrm{O}_{8}$ sample exhibited unique intercalation behavior for water molecules through hydrogen bonding, which also contributed to the enhanced activity.

\subsection{MOF-based photocatalysts}

MOFs, a novel class of porous materials consisting of metal-containing clusters and organic ligands, have attracted 

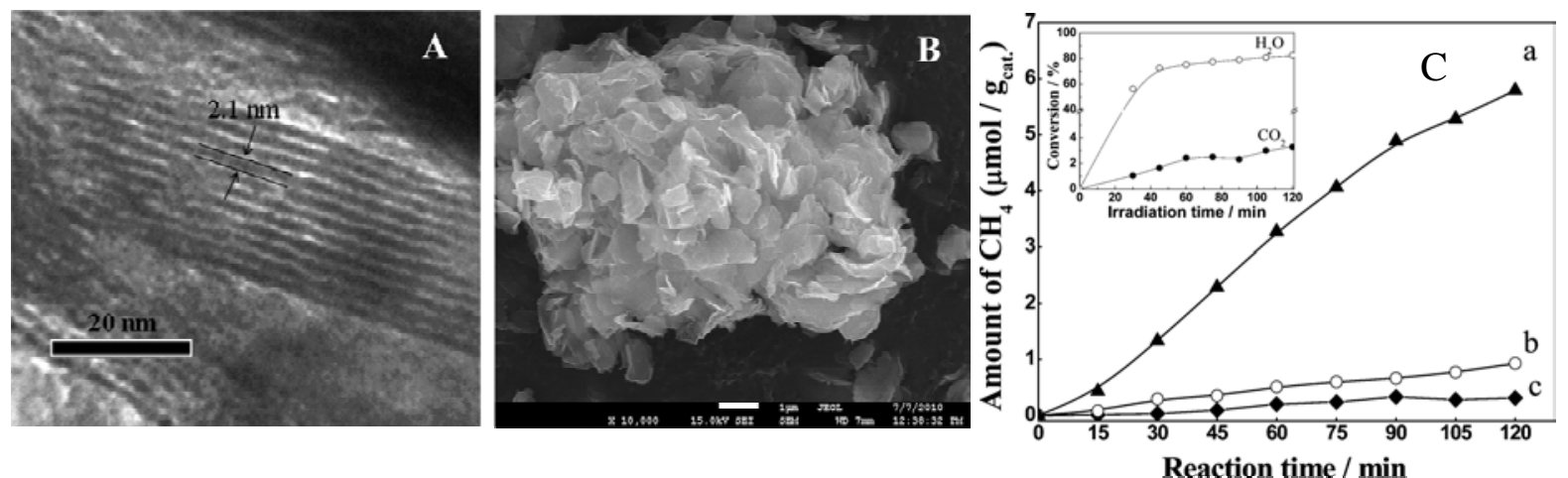

Fig. 7. (A) TEM and (B) SEM images of $\mathrm{SiO}_{2}$-pillared $\mathrm{HNb}_{3} \mathrm{O}_{8}$; (C) Photocatalytic reduction of $\mathrm{CO}_{2}$ over (a) $\mathrm{SiO}_{2}-\mathrm{HNb}_{3} \mathrm{O}_{8},\left(\right.$ b) $\mathrm{HNb}_{3} \mathrm{O}_{8}, \mathrm{and}$ (c) $\mathrm{Nb}_{2} \mathrm{O}_{5}$. Copyright permission from American Chemistry Society, Ref. [112].

growing interests in diverse fields, particularly in gas adsorption/separation and catalysis. In addition to their high gas uptake capability, MOFs are semiconductors or insulators with a band gap of 1.0-5.5 eV. Under light irradiation, the ligands can capture photons, resulting in electron transfer from the ligands to the metal. To improve the photocatalytic activity of MOFs, two crucial problems need to be addressed: broadening the spectral response range and improving the quantum efficiency.

The modification of MOF materials by chromophores, chelates, or metal complexes is an effective way to extend the spectral response range. For example, Sun et al. [113] reported MOF-253- $\mathrm{Ru}(\mathrm{CO})_{2} \mathrm{Cl}_{2}$ for photocatalytic CRR (Fig. 8). The pure MOF-253 alone did not show absorption in the visible-light region. When coordinating to $\mathrm{Ru}(\mathrm{II})$ via $\mathrm{N}, \mathrm{N}$-chelating sites, the absorption edge of the as-prepared MOF-253- $\mathrm{Ru}(\mathrm{CO})_{2} \mathrm{Cl}_{2}$ extended to $470 \mathrm{~nm}$. Approximately $0.67 \mu \mathrm{mol}$ of $\mathrm{HCOO}^{-}, 1.86$ $\mu \mathrm{mol}$ of $\mathrm{CO}$, and $0.09 \mu \mathrm{mol} \mathrm{H}_{2}$ were produced after irradiation for $8 \mathrm{~h}$. Another report introduced ruthenium-based dye as a photosensitizer to cooperate with ZIF-67 material. The photocatalytic performance toward CRR increased to $37.4 \mu \mathrm{mol} / 30$ min for the CO generation rate [114].

Recent studies [115-117] have reported that some MOF materials such as UiO-66 can exhibit semiconductor behavior with active sites for the photocatalytic CRR despite their rather low efficiency. To improve the quantum efficiency, the re- searchers explored various MOF materials with high $\mathrm{CO}_{2}$ capture capacity for coupling with photocatalysts. Yan et al. [118] fabricated a Co-ZIF-9/ $\mathrm{TiO}_{2}$ composite (ZIFx/T) with a welldesigned nanostructure in which $\mathrm{TiO}_{2}$ and Co-ZIF-9 were closely bound with each other. After $10 \mathrm{~h}$ of UV-visible light irradiation, ZIF0.03/T exhibited the highest photocatalytic activity with a total NUPN (UPN, utilized photoelectron number) of $28.17 \mu \mathrm{mol}$, which was approximately 2.1 times that of the pure $\mathrm{TiO}_{2}$. The well-ordered porous structure and imidazolate motifs of Co-ZIF-9 are essential for $\mathrm{CO}_{2}$ adsorption/activation and thus result in the superior CRR activity. This work revealed that coupling $\mathrm{TiO}_{2}$ with MOFs greatly improved the photocatalytic activity toward CRR as compared with pure $\mathrm{TiO}_{2}$. To achieve further utilization of the visible region in solar energy, MOF materials could be combined with semiconductors that are responsive to visible light. A series of $\mathrm{Cd}_{0.2} \mathrm{Zn}_{0.8} \mathrm{~S} @ \mathrm{UiO}-66-\mathrm{NH}_{2}$ nanocomposites with different UiO-66- $\mathrm{NH}_{2}$ contents were fabricated via a solvothermal method [119]. The optimal composite (20 wt $\%$ of UiO-66- $\mathrm{NH}_{2}$ ) exhibited a $\mathrm{CH}_{3} \mathrm{OH}$ production rate of $6.8 \mu \mathrm{mol} \mathrm{h}^{-1} \mathrm{~g}^{-1}$ under visible-light irradiation. This remarkable enhancement of the photocatalytic activity can be attributed to the efficient charge separation and transfer on the interface between $\mathrm{Cd}_{0.2 \mathrm{Zn}} \mathrm{Zn}_{0.8} \mathrm{~S}$ and UiO-66- $\mathrm{NH}_{2}$. Liu et al. [120] decorated tubular g- $\mathrm{C}_{3} \mathrm{~N}_{4}$ with transparent zeolitic imidazolate framework-8 (ZIF-8) nanoclusters. The photocatalytic rate of
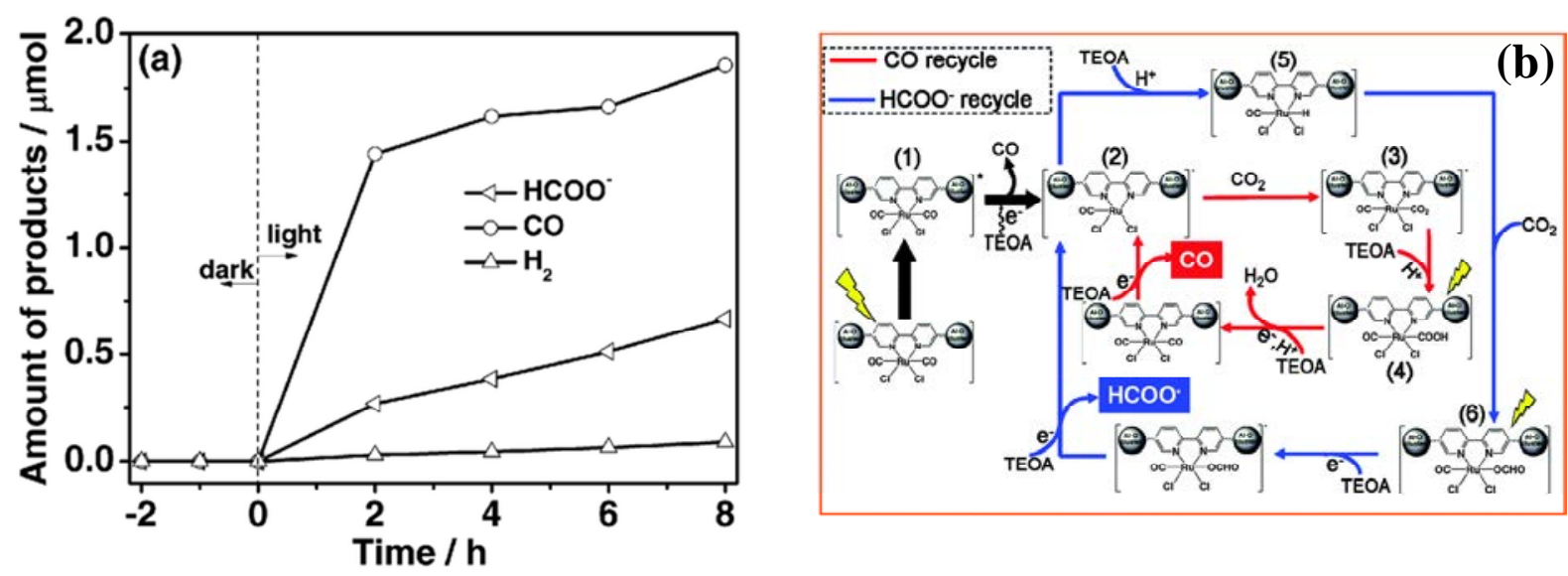

Fig. 8. (a) Amount of products produced as a function of irradiation time over MOF-253- $\mathrm{Ru}(\mathrm{CO})_{2} \mathrm{Cl}_{2}$; (b) Proposed mechanism for photocatalytic $\mathrm{CRR}$ over the as-prepared MOF-253-Ru(CO) ${ }_{2} \mathrm{Cl}_{2}$ under visible light. Copyright permission from Royal Society of Chemistry, Ref. [113]. 
$\mathrm{CH}_{3} \mathrm{OH}$ production reached $0.75 \mu \mathrm{mol} \mathrm{h} \mathrm{h}^{-1} \mathrm{~g}^{-1}$, which was more than 3 times greater than that of bulk g- $\mathrm{C}_{3} \mathrm{~N}_{4}$ photocatalysts. Nanosized carbon nitride nanosheets were incorporated with Ui0-66 for photocatalytic CRR (Fig. 9). This hybrid structure exhibited a large surface area and strong $\mathrm{CO}_{2}$ capture ability due to the introduction of UiO-66. The UiO-66/CNNS composite exhibited a high $\mathrm{CO}$ yield of $59.4 \mu \mathrm{mol} / \mathrm{g}_{\mathrm{CN}}$ under visible-light illumination for $6 \mathrm{~h}$; this value was more than three times that of CNNS (17.1 $\left.\mu \mathrm{mol} / \mathrm{g}_{\mathrm{CN}}\right)$ [121].

In addition to MOFs cooperating with semiconductors, there are several reports about combining MOF materials with metal nanoparticles. As reported by Choi et al. [122], Ag nanocubes with surface plasma resonance (SPR) effect were coated with

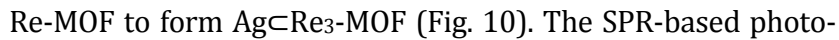
catalysts exhibited 5-fold enhancement of activity over $\mathrm{Re}_{3}-\mathrm{MOF}$ under visible light. Moreover, the ReTCs covalently binding within the MOFs benefited their long-term stability. Zhang et al. [123] discovered that anchoring atomically dispersed catalysts (e.g., mononuclear metal complexes or single metal atoms) on supports resulted in maximum atom efficiency. They coordinatively incorporated an unsaturated single atom into a MOF matrix. The porphyrin MOFs comprising atomically dispersed catalytic centers exhibited significantly enhanced photocatalytic conversion of $\mathrm{CO}_{2}$, which was equivalent to a 3.13-fold improvement in the $\mathrm{CO}$ evolution rate $(200.6$ $\mu \mathrm{mol} \mathrm{g}^{-1} \mathrm{~h}^{-1}$ ) and a 5.93-fold enhancement in the $\mathrm{CH}_{4}$ generation rate $\left(36.67 \mu \mathrm{mol} \mathrm{g}^{-1} \mathrm{~h}^{-1}\right)$ compared with those of the parent MOFs. The results revealed that the presence of single Co atoms in the MOF can greatly boost the electron-hole separation efficiency in porphyrin units.

\subsection{MOP-based photocatalysts}

Compared with other porous materials, MOP materials possess remarkable stability in strong acidic and basic mediums [124]. Most MOP-based catalysts can be divided into two types.
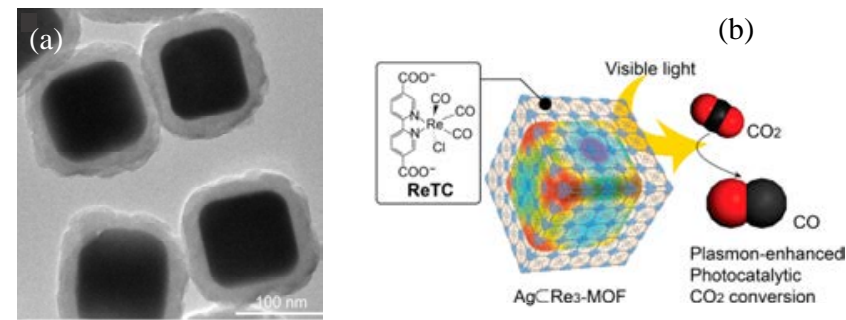

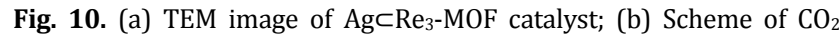
photoreduction over $\mathrm{Ag} \subset \mathrm{Re}_{3}-\mathrm{MOF}$ catalyst. Copyright permission from American Chemistry Society, Ref. [122].

In one type, the nonmetallic catalytic active center is embedded into the skeleton to construct intrinsic polymer catalysts, and in the other type, catalyst particles or ions are loaded on the surface or within the channels of MOP supports. As typical MOP materials, COFs with a large $\pi$-conjugated structure possess excellent $\mathrm{CO}_{2}$ absorption capacity and conductivity. In addition, their high surface area and tunable porosity as well as crystalline and stable skeletons make them attractive support matrices for loading nanoparticles [125]. Thus, COFs with visible light absorption show potential for application in the field of photocatalysis [126].

In 2013, Schwinghammer et al. [127] prepared triazine-doped metal salts PTI $/ \mathrm{Li}^{+} \mathrm{Cl}^{-}$and heptazine-based COFs, which displayed photocatalytic activity with hydrogen production rates of 864 and $722 \mu \mathrm{mol} \mathrm{h}^{-1} \mathrm{~g}^{-1}$, respectively. In 2014, Lotsch et al. [128] prepared hydrazone-linked nitrogen-rich TFPT-COF materials with visible-light-driven photoactivity (Fig. 11). The hydrogen production efficiency reached as high as $1970 \mu \mathrm{mol} \mathrm{h}^{-1} \mathrm{~g}^{-1}$, and the quantum efficiency reached $2.2 \%$ in the presence of $10 \%$ triethanolamine solution as an electron sacrificial agent. Thote et al. [129] deposited CdS nanoparticles on a two-dimensional (2D) COF matrix. The CdS-COF (90:10) hybrid exhibited a hydrogen production rate of $3678 \mu \mathrm{mol} \mathrm{h}-1$ $\mathrm{g}^{-1}$, which was significantly higher than that of bulk CdS parti-

(a)

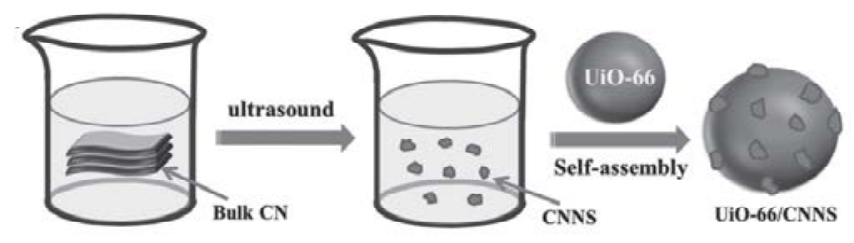

(b)

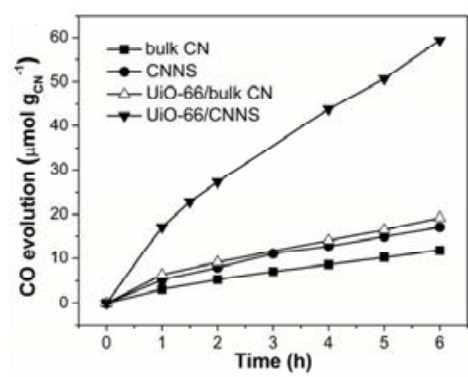

(c)

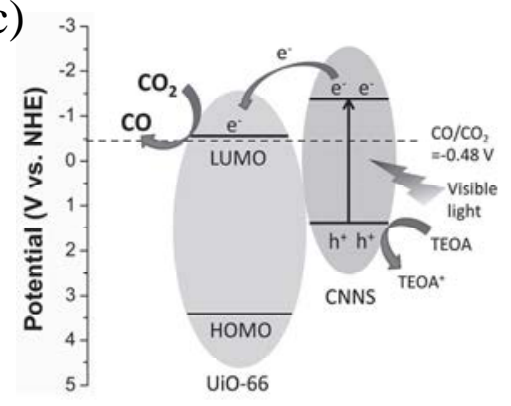

Fig. 9. (a) Schematic illustration of the preparation of the UiO-66/CNNS heterogeneous photocatalyst; (b) Time course of CO evolution over bulk CN, CNNS, UiO-66/bulk CN, and UiO-66/CNNS photocatalysts; (c) Proposed mechanism of photocatalytic reduction of $\mathrm{CO}_{2}$ by the UiO-66/CNNS heterogeneous photocatalyst under visible-light irradiation. Copyright permission from John Wiley and Sons, Ref. [121]. 


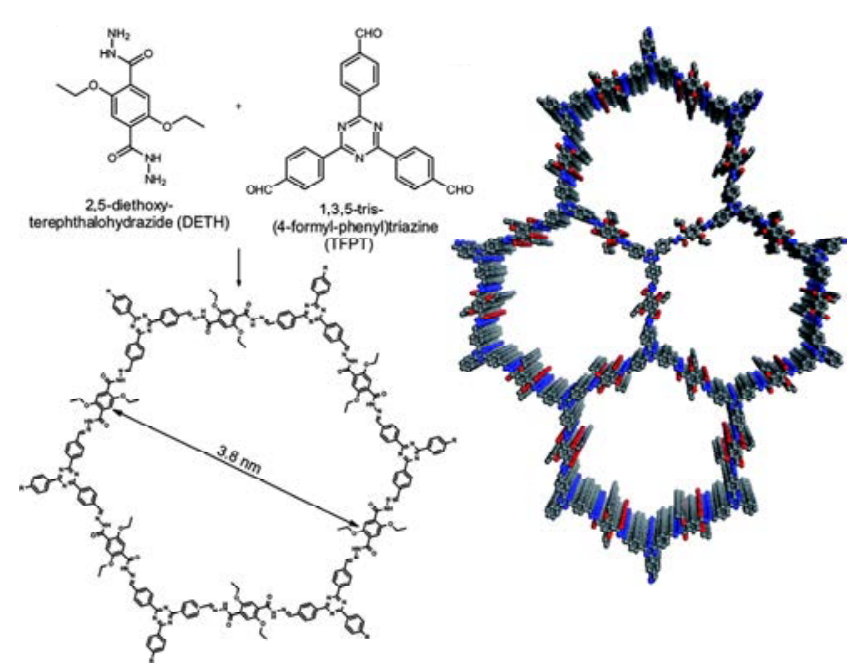

Fig. 11. Design and synthesis of TFPT-COF. Copyright permission from Royal Society of Chemistry, Ref. [128].

cles $\left(124 \mu \mathrm{mol} \mathrm{h}^{-1} \mathrm{~g}^{-1}\right)$. The structural merits of the COF materials, such as the $\pi$-conjugated structure, high surface area, and abundant 2D hetero-interface, highlighted their effectiveness as supports for stabilizing the catalyst nanoparticles and improving the charge carrier separation, thereby resulting in a high photocatalytic activity.

Research on MOP-based photocatalysts has mainly focused on photocatalytic hydrogen production. To date, there are no reports on photocatalytic $\mathrm{CO}_{2}$ conversion to the best of our knowledge. The absence of MOPs in photocatalytic CRR can presumably be attributed to their low photocatalytic performance relative to semiconductor photocatalysts according to recent reports. For example, biphenyl and bipyridine copolymers containing trace amounts of Pt exhibited apparent quantum efficiency (AQE) of hydrogen production of only $1.8 \%$ at $350 \mathrm{~nm}$ [130]. In addition, the AQE of conjugated microporous polymer by benzene-ring crosslinking was only $2.3 \%$ toward hydrogen production at $420 \mathrm{~nm}$ [131]. Although there are extensive reports on their use for gas adsorption/separation and catalysis, the application of MOP-based photocatalysts toward CRR is worthy of in-depth study in the future.

\subsection{Other modifications of photocatalysts}

In addition to combining photocatalysts with porous materials, there are other modifications that can be used to enhance the adsorption and photocatalytic reduction performance of $\mathrm{CO}_{2}$, such as alkali modification, impurity doping, metal deposition, and heterojunction construction [132-134]. The alkali modification of photocatalysts has been considered one of the most efficient ways to enhance the adsorption capacity of $\mathrm{CO}_{2}$ by enabling chemisorption through alkali sorbents and then improving the photocatalytic $\mathrm{CO}_{2}$ reduction efficiency. For example, Meng et al. [135] demonstrated that the alkali modification of $\mathrm{TiO}_{2}$ by $\mathrm{NaOH}$ could greatly improve the chemisorption and activation of $\mathrm{CO}_{2}$ on $\mathrm{TiO}_{2}$ photocatalysts. The photocatalytic $\mathrm{CO}_{2}$ reduction activity of the optimal sample calcined with 3 $w t \%$ of $\mathrm{NaOH}$ was observed to be far higher than that of pure
$\mathrm{TiO}_{2}$. The introduction of $\mathrm{NaOH}$ can activate the $\mathrm{CO}_{2}$ molecule by promoting the formation of bidentate carbonate species. Liu et al. [136] reported an earth-abundant alkaline mineral, $\mathrm{MgO}$ coupled $\mathrm{TiO}_{2}\left(\mathrm{MgO}-\mathrm{TiO}_{2}\right)$, for enhancing the photocatalytic $\mathrm{CO}_{2}$ reduction activity. The addition of $\mathrm{MgO}$ significantly enhanced the $\mathrm{CO}_{2}$ adsorption ability of $\mathrm{TiO}_{2}$ and limited the adsorption of $\mathrm{H}_{2} \mathrm{O}$ molecules. Therefore, the competitive $\mathrm{H}_{2} \mathrm{O}$ water splitting reaction on conventional photocatalysts could be avoided on the $\mathrm{MgO}^{-\mathrm{TiO}_{2}}$.

Table 4 summarizes the findings of recent reports on $\mathrm{CO}_{2}$ reduction in both gas-liquid and gas-solid reaction systems. The production rates of the main products, such as $\mathrm{CO}, \mathrm{CH}_{4}$, and $\mathrm{CH}_{3} \mathrm{OH}$ over these photocatalysts were very low. After alkali modification on photocatalysts, because of the chemical adsorption with $\mathrm{CO}_{2}$ molecules in the photocatalytic process, the CRR catalytic efficiency increased to approximately 2 times that of the pristine photocatalysts. In particular, when combining the porous materials with semiconductors, the conversion efficiency of $\mathrm{CO}_{2}$ molecules appeared to significantly improve, and the change was more notable than with the other modifications. This improvement could be attributed to the improved $\mathrm{CO}_{2}$ adsorption by porous materials with larger surface area, especially in the MOF-based photocatalytic system.

Even though a great enhancement in activity has been achieved, the current state of photocatalytic $\mathrm{CO}_{2}$ reduction is far from satisfactory for practical applications. Many open issues and challenges remain, which require further research efforts. First, these porous materials suffer from a certain degree of instability in the processes of $\mathrm{CO}_{2}$ adsorption and photocatalytic reduction, such as the poor water resistance of IPMs, thermal-/photo-instability of MOFs and MOPs, and poor stability under acidic or alkaline conditions. Second, the specific surface area and $\mathrm{CO}_{2}$ adsorption capacity substantially decreased after incorporating photocatalysts into the porous materials. Finally, the mechanism of photocatalytic $\mathrm{CO}_{2}$ reduction is not yet clear, which has restricted the development of efficient photocatalysts. Therefore, more studies in this field are urgently needed to explore new synthesis methodologies and in-depth mechanisms for further enhancing the photocatalytic performance of porous materials toward $\mathrm{CO}_{2}$ conversion.

\section{Conclusions and perspectives}

In summary, this review highlighted the significant achievements made in the design and fabrication of porous nanomaterials for adsorption and photocatalytic conversion of the "greenhouse gas" $\mathrm{CO}_{2}$. According to the systematic research on gas adsorption and separation, the construction of photocatalysts toward $\mathrm{CO}_{2}$ conversion is based on three classes of porous nanomaterials: IPMs, MOFs, and MOPs. Compared with IPMs, MOFs and MOPs possess distinct superiority in supporting photocatalysts for CRR because of their high surface area, tunable pore structures, and feasible skeleton modification. Benefiting from the improved $\mathrm{CO}_{2}$ uptake capacity, the porous-material-based photocatalysts have exhibited remarkably enhanced efficiency in the reduction of $\mathrm{CO}_{2}$ to chemical fuels, such as $\mathrm{CO}, \mathrm{CH}_{4}$, and $\mathrm{CH}_{3} \mathrm{OH}$. The results are compared and 
Table 4

Summary of recent reports on $\mathrm{CO}_{2}$ conversion efficiency over porous-material-based photocatalysts.

\begin{tabular}{|c|c|c|c|c|}
\hline Catalyst & Light source & co-catalyst & Products $\left(\mu \mathrm{mol} \mathrm{g}^{-1} \mathrm{~h}^{-1}\right)$ & Ref. \\
\hline \multicolumn{5}{|l|}{ I. Gas-liquid reaction system } \\
\hline \multicolumn{5}{|l|}{ i. Traditional photocatalyst } \\
\hline $\mathrm{g}-\mathrm{C}_{3} \mathrm{~N}_{4}$ & 300 W Xe lamp & $\mathrm{Pd}$ & $\mathrm{CH}_{4}: 0.4 \mathrm{CH}_{3} \mathrm{OH}: 3.17$ & [137] \\
\hline $\mathrm{N}-\mathrm{TiO}_{2} \mathrm{MS}$ & 300 W Xe lamp & & $\mathrm{CH}_{3} \mathrm{OH}: 0.36$ & [138] \\
\hline \multicolumn{5}{|l|}{ ii. Porous material-based photocatalyst } \\
\hline carbon@ $\mathrm{TiO}_{2}$ hollow spheres & 300 W Xe lamp & - & $\mathrm{CH}_{4}: 4.2 \mathrm{CH}_{3} \mathrm{OH}: 9.1$ & {$[90]$} \\
\hline 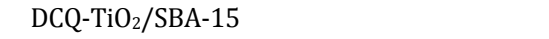 & 100W halide lamp & - & $\mathrm{CH}_{3} \mathrm{OH}: 0.44$ & {$[110]$} \\
\hline $\mathrm{Cd}_{0.2} \mathrm{Zn}_{0.8} \mathrm{~S} @ U \mathrm{UiO}-66-\mathrm{NH}_{2}$ & Visible light irradiation $(\lambda>420 \mathrm{~nm})$ & - & $\mathrm{CH}_{3} \mathrm{OH}: 6.8$ & [119] \\
\hline $\mathrm{g}-\mathrm{C}_{3} \mathrm{~N}_{4} / \mathrm{ZIF}-8$ & 300 W Xe lamp & - & $\mathrm{CH}_{3} \mathrm{OH}: 0.75$ & [120] \\
\hline MOF-253-Ru(CO) ${ }_{2} \mathrm{Cl}_{2}$ & Visible light irradiation $(\lambda>420 \mathrm{~nm})$ & - & HCOO: 16.75 CO: 46.5 & [113] \\
\hline \multicolumn{5}{|l|}{ II. Gas-solid reaction system } \\
\hline \multicolumn{5}{|l|}{ i. Traditional photocatalyst } \\
\hline $\mathrm{S}-\mathrm{TiO}_{2}$ & Visible light irradiation $(\lambda>400 \mathrm{~nm})$ & & $\mathrm{CH}_{4}: 3.3$ & [139] \\
\hline $\mathrm{TiO}_{2} / \mathrm{g}-\mathrm{C}_{3} \mathrm{~N}_{4}$ & Visible light irradiation $(\lambda>400 \mathrm{~nm})$ & - & $\mathrm{CO}: 0.84 \mathrm{CH}_{4}: 5.21$ & [140] \\
\hline $\mathrm{NaOH}-\mathrm{TiO}_{2}$ & 300 W Xe lamp & & $\mathrm{CH}_{4}: 8.7$ & [135] \\
\hline${\mathrm{MgO}-\mathrm{TiO}_{2}}_{2}$ & 400 W Xe lamp & & CO: 21.0 & [136] \\
\hline \multicolumn{5}{|l|}{ ii. Porous material-based photocatalyst } \\
\hline $\mathrm{C}-\mathrm{In}_{2} \mathrm{O}_{3}$ & 300 W Xe lamp & $2 w t \% \mathrm{Pt}$ & $\mathrm{CO}: 126.6 \mu \mathrm{mol} / \mathrm{h} \mathrm{CH}_{4}: 27.9 \mu \mathrm{mol} / \mathrm{h}$ & {$[96]$} \\
\hline $\mathrm{Cu} / \mathrm{TiO}_{2}-\mathrm{SiO}_{2}$ & Xe arc Lamp & $0.5 \mathrm{wt} \% \mathrm{Cu}$ & $\mathrm{CO}: 60 \mathrm{CH}_{4}: 10$ & [111] \\
\hline $\mathrm{SiO}_{2}-\mathrm{HNb}_{3} \mathrm{O}_{8}$ & 350 W Xe lamp & $0.4 \mathrm{wt} \% \mathrm{Pt}$ & $\mathrm{CH}_{4}: 2.9$ & [112] \\
\hline Co-ZIF-9/TiO 2 & 300 W Xe lamp & - & $\mathrm{CO}: 0.879 \mu \mathrm{mol} / \mathrm{h} \mathrm{CH}_{4}: 0.099 \mu \mathrm{mol} / \mathrm{h}$ & [118] \\
\hline UiO-66/CNNS & Visible light irradiation $(\lambda>420 \mathrm{~nm})$ & - & CO: $9.9 \mu \mathrm{mol} \mathrm{g}_{\mathrm{CN}}^{-1} \mathrm{~h}^{-1}$ & [121] \\
\hline ZIF-67 co-operated with $\left[\mathrm{Ru}(\mathrm{bpy})_{3}\right] \mathrm{Cl}_{2} \cdot 6 \mathrm{H}_{2} \mathrm{O}$ & Visible light irradiation $(\lambda>420 \mathrm{~nm})$ & ZIF-67 & $\mathrm{CO}: 37.4 \mu \mathrm{mol} / 30 \mathrm{~min}$ & [114] \\
\hline MOF-525-Co & Visible light irradiation $(\lambda>420 \mathrm{~nm})$ & & $\mathrm{CO}: 200.6 \mathrm{CH}_{4}: 36.76$ & [123] \\
\hline
\end{tabular}

summarized in Table 4. It is noteworthy that the $\mathrm{CO}_{2}$ adsorption and conversion efficiency remain far from those needed for practical application in carbon resources recycling. Many open issues and challenges remain, which require further research efforts. First, more studies are needed to improve the stability of porous materials, such as the water resistance of IPMs and thermal-/photo-stability of MOFs and MOPs. Second, the development of high-performance photocatalysts on porous supports without sacrificing the $\mathrm{CO}_{2}$ adsorption capacity is highly desired. Finally, the in-depth study of the photocatalytic mechanisms of CRR must be reinforced to provide theoretical foundations to boost further advancements in this field. Overall, we believe that the development of porous photocatalysts with high $\mathrm{CO}_{2}$ uptake is a direction with high potential that is worthy of further investigations for photocatalytic $\mathrm{CO}_{2}$ conversion.

\section{References}

[1] National Aeronautics and Space Administration (NASA) USA, Climate Change: Vital Signs of the Planet: Carbon Dioxide, 2017, http://climate.nasa.gov/vital-signs/carbon-dioxide/ (accessed 30.10.2017).

[2] P. Luckow, M. A. Wise, J. J. Dooley, S. H. Kim, Int. J. Greenh. Gas. Control, 2010, 4, 865-871.

[3] Y. Zhao, Y. X. Pan, Y. Xie, C. J. Liu, Catal. Commun., 2008, 9, 1558-1562.

[4] E. Jacob-Lopes, C. H. G. Scoparo, M. I. Queiroz, T. T. Franco, Energy Conv. Manag., 2010, 51, 894-900.

[5] X. B. Zhu, Qu Xin, S. X. Li, J. L. Liu, J. H. Liu, B. Zhu, C. Shi, Chin. J.
Catal., 2016, 37, 2035-2058.

[6] J. X. Low, J. G. Yu, K. W. Ho, J. Phys. Chem. Lett., 2015, 6, 4244-4251. [7] J. Jin, J. G. Yu, D. P. Guo, C. Cui, W. Ho, Small, 2015, 11, 5262-5271.

[8] J. Mao, T. Y. Peng, X. H. Zhang, K. Li, L. Q. Ye, L. Zan, Catal. Sci. Technol., 2013, 3, 1253-1260.

[9] J. Mao, T. Y. Peng, X. H. Zhang, K. Li, L. Zan, Catal. Commun., 2012, 28, 38-41.

[10] K. Li, B. Peng, T. Y. Peng, ACS Catal., 2016, 6, 7485-7527.

[11] P. F. Xia, B. C. Zhu, J. G. Yu, S. W. Cao, M. Jaroniec, J. Mater. Chem. A, 2017, 5, 3230-3238.

[12] W. L. Yu, D. F. Xu, T. Y. Peng, J. Mater. Chem. A, 2015, 3, 19936-19947.

[13] C. J. Wang, R. L. Thompson, P. Ohodnicki, J. Baltrus, C. Matranga, J. Mater. Chem., 2011, 21, 13452-13457.

[14] P. Li, Y. Zhou, H. J. Li, Q. F. Xu, X. G. Meng, X. Y. Wang, M. Xiao, Z. G. Zou, Chem. Commun., 2015, 51, 1743-1743.

[15] J. C. Wang, A. Heerwig, M. R. Lohe, M. Oschatz, L. Borchardt, S. Kaskel, J. Mater. Chem., 2012, 22, 13911-13913.

[16] M. G. Plaza, C. Pevida, A. Arenillas, F. Rubiera, J. J. Pis, Fuel, 2007, $86,2204-2212$.

[17] Z. X. Wu, N. Hao, G. K. Xiao, L. Y. Liu, P. Webley, D. Y. Zhao, Phys. Chem. Chem. Phys., 2011, 13, 2495-2503.

[18] G. P. Hao, W. C. Li, D. Qian, A. H. Lu, Adv. Mater., 2010, 22, 853-857.

[19] M. R. Hudson, W. L. Queen, J. A. Mason, D. W. Fickel, R. F. Lobo, C. M. Brown, J. Am. Chem. Soc., 2012, 134, 1970-1973.

[20] L. Grajciar, J. Čejka, A. Zukal, C. Otero Areán, G. Turnes Palomino, P. Nachtigall, ChemSusChem, 2012, 5, 2011-2022.

[21] Z. Y. Li, Y. S. Tu, Z. H. Yang, Ind. Catal., 2005, 13, 12-18.

[22] Z. Bacsik, N. Ahlsten, A. Ziadi, G. Zhao, A. E. Garcia-Bennett, B. Martin-Matute, N. Hedin, Langmuir, 2011, 27, 11118-111128.

[23] A. Heydarigorji, Y. Belmabkhout, A. Sayari, Langmuir, 2011, 27, 12411-12416. 
[24] Y. Kuwahara, D. Y. Kang, J. R. Copeland, P. Bollini, C. Sievers, T. Kamegawa, H. Yamashita, C. W. Jones, Chem. Eur. J., 2012, 18, 16649-16664.

[25] L. T. L. Nguyen, C. V. Nguyen, G. H. Dang, K. K. A. Le, N. T. S. Phan, J. Mol. Catal. A, 2011, 349, 28-35.

[26] J. L. Rowsell, 0. M. Yaghi, Angew. Chem. Int. Ed., 2005, 44, 4670-4679.

[27] H. C. Zhou, J. R. Long, O. M. Yaghi, Chem. Rev., 2012, 112, 673-674.

[28] S. Keskin, T. M. van Heest, D. S. Sholl, ChemSusChem, 2010, 3, 879-891.

[29] L. Tan, B. Tan, Chem. Soc. Rev., 2017, 46, 3322-3356.

[30] Y. F. Zeng, R. Q. Zou, Y. L. Zhao, Adv. Mater., 2016, 28, 2855-2873.

[31] Y. Wang, J. Zhao, T. F. Wang, Y. X. Li, X. Y. Li, J. Yin, C. Y. Wang, J. Catal., 2016, 337, 293-302.

[32] J. Wilcox, R. Haghpanah, C. E. Rupp, J. J. He, K. Lee, Annu. Rev. Chem. Biomol. Eng., 2014, 5, 479-505.

[33] H. Xu, W. Chu, X. Huang, W. J. Sun, C. F. Jiang, Z. Q. Liu, Appl. Surf. Sci., 2016, 375, 196-206.

[34] J. Silvestre-Albero, A. Wahby, A. Sepulveda-Escribano, M. Martinez-Escandell, K. Kaneko, F. Rodriguez-Reinoso, Chem. Commun., 2011, 47, 6840-6842.

[35] W. Z. Shen, S. C. Zhang, Y. He, J. F. Li, W. B. Fan, J. Mater. Chem., 2011, 21, 14036-14040.

[36] X. T. Zhang, D. H. Lin, W. X. Chen, RSC Adv, 2015, 5, 45136-45143.

[37] P. D. Jadhav, R. V. Chatti, R. B. Biniwale, N. K. Labhsetwar, S. Devotta, S. S. Rayalu, Energy Fuels, 2007, 21, 3555-3559.

[38] F. S. Su, C. Y. Lu, S. C. Kuo, W. Zeng, Energy Fuels, 2010, 24, 1441-1448.

[39] P. J. E. Harlick, A. Sayari, Ind. Eng. Chem. Res., 2006, 45, 3248-3255.

[40] P. J. E. Harlick, A. Sayari, Ind. Eng. Chem. Res., 2007, 46, 446-458.

[41] H. Y. Huang, R. T. Yang, D. Chinn, C. L. Munson, Ind. Eng. Chem. Res., 2003, 42, 2427-2433.

[42] H. L. Zhao, J. Hu, J. G. Wang, L. H. Zhou, H. L. Liu, Acta Phys. Chim. Sin., 2007, 23, 801-806.

[43] M. B. Yue, L. B. Sun, Y. Cao, Y. Wang, Z. J. Wang, J. H. Zhu, Chem. Eur. J., 2008, 14, 3442-3451.

[44] G. R. Serna, E. Da'Na, A. Sayari, Ind. Eng. Chem. Res., 2008, 47, 9406-9412.

[45] X. C. Xu, C. S. Song, J. M. Andrésen, B. G. Miller, A. W. Scaroni, Microporous Mesoporous Mater., 2003, 62, 29-45.

[46] M. B. Yue, Y. Chun, Y. Cao, X. Dong, J. H. Zhu, Adv. Funct. Mater., 2006, 16, 1717-1722.

[47] M. B. Yue, L. B. Sun, Y. Cao, Z. J. Wang, Y. Wang, Q. Yu, J. H. Zhu,
Microporous Mesoporous Mater., 2008, 114, 74-81.

[48] J. H. Drese, S. Choi, R. P. Lively, W. J. Koros, D. J. Fauth, M. L. Gray, C. W. Jones, Adv. Funct. Mater., 2009, 19, 3821-3832.

[49] F. Y. Chang, K. J. Chao, H. H. Cheng, C. S. Tan, Sep. Purif. Technol., 2009, 70, 87-95.

[50] M. Bhagiyalakshmi, R. Anuradha, S. D. Park, H. T. Jang, Microporous Mesoporous Mater., 2010, 131, 265-273.

[51] M. Bhagiyalakshmi, S. D. Park, W. S. Cha, H. T. Jang, Appl. Surf. Sci., 2010, 256, 6660-6666.

[52] J. Y. An, N. L. Rosi, J. Am. Chem. Soc., 2010, 132, 5578-5579.

[53] A. R. Millward, O. M. Yaghi, J. Am. Chem. Soc., 2005, 127, 17998-17999.

[54] P. L. Llewellyn, S. Bourrelly, C. Serre, A. Vimont, M. Daturi, L. Hamon, G. De Weireld, J. S. Chang, D. Y. Hong, Y. Kyu Hwang, S. Hwa Jhung, G. Férey, Langmuir, 2008, 24, 7245-7250.

[55] H. Furukawa, N. Ko, Y. B. Go, N. Aratani, S. B. Choi, E. Choi, A. O. Yazaydin, R. Q. Snurr, M. O'Keeffe, J. Kim, O. M. Yaghi, Science, 2010, 329, 424-428.

[56] D. Britt, H. Furukawa, B. Wang, T. G. Glover, O. M. Yaghi, Proc. Natl. Acad. Sci. USA, 2009, 106, 20637-20640.

[57] A. O. Yazaydin, R. Q. Snurr, T. H. Park, K. Koh, J. Liu, M. D. Levan, A. I. Benin, P. Jakubczak, M. Lanuza, D. B. Galloway, J. J. Low, R. R. Wills, J. Am. Chem. Soc., 2009, 131, 18198-18199.

[58] P. D. C. Dietzel, V. Besikiotis, R. Blom, J. Mater. Chem., 2009, 19, 7362-7370.

[59] S. R. Caskey, A. G. Wongfoy, A. J. Matzger, J. Am. Chem. Soc., 2008, 130, 10870-10871.

[60] P. Nugent, Y. Belmabkhout, S. D. Burd, A. J. Cairns, R. Luebke, K. Forrest, T. Pham, S. Ma, B. Space, L. Wojtas, M. Eddaoudi, M. J. Zaworotko, Nature, 2013, 495, 80-84.

[61] J. W. Yoon, S. H. Jhung, Y. K. Hwang, S. M. Humphrey, P. T. Wood, J. S. Chang, Adv. Mater., 2007, 19, 1830-1834.

[62] K. L. Mulfort, O. K. Farha, C. D. Malliakas, M. G. Kanatzidis, J. T. Hupp, Chem. Eur. J., 2010, 16, 276-281.

[63] H. S. Choi, M. P. Suh, Angew. Chem. Int. Ed., 2009, 48, 6865-6869.

[64] J. An, S. J. Geib, N. L. Rosi, J. Am. Chem. Soc., 2010, 132, 38-39.

[65] J. Gascon, U. Aktay, M. D. Hernandez-Alonso, G. Van klink, F. Kapteijn, J. Catal., 2009, 261, 75-87.

[66] T. Wu, L. Shen, M. Luebbers, C. Hu, Q. Chen, Z. Ni, R. I. Masel, Chem. Commun., 2010, 46, 6120-6122.

[67] W. Zhang, Y. Hu, J. Ge, H. L. Jiang, S. H. Yu, J. Am. Chem. Soc., 2014, 136, 16978-16981.

[68] J. G. Nguyen, S. M. Cohen, J. Am. Chem. Soc., 2010, 132, 4560-4561.

[69] B. Z. Yuan, D. Y. Ma, X. Wang, Z. Li, Y. W. Li, H. M. Liu, D. H. He, Chem.

\section{Graphical Abstract}

Chin. J. Catal., 2017, 38: 1956-1969 doi: 10.1016/S1872-2067(17)62955-3

Review on porous nanomaterials for adsorption and photocatalytic conversion of $\mathrm{CO}_{2}$

Yajuan Ma, Zemei Wang, Xiaofeng Xu, Jingyu Wang * Huazhong University of Science and Technology

This review summarizes advances in the development of porous materials for $\mathrm{CO}_{2}$ adsorption and photocatalytic conversion. Benefiting from improved $\mathrm{CO}_{2}$ uptake, porous photocatalysts exhibit remarkably enhanced efficiency in the reduction of $\mathrm{CO}_{2}$ to chemical fuels.

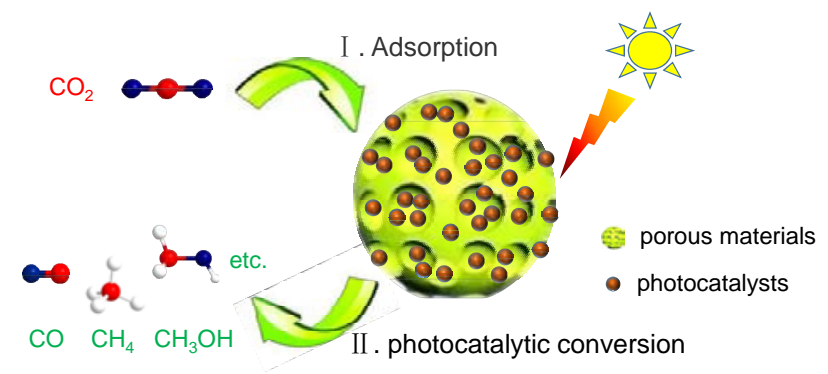

Porous photocatalysts 
Commun., 2012, 48, 1135-1137.

[70] Y. F. Zhao, K. X. Yao, B. Y. Teng, T. Zhang, Y. Han, Energy Environ. Sci., 2013, 6, 3684-3692.

[71] R. Dawson, E. Stöckel, J. R. Holst, D. J. Adams, A. I. Cooper, Energy Environ. Sci., 2011, 4, 4239-4245.

[72] C. F. Martín, E. Stöckel, R. Clowes, D. J. Adams, A. I. Cooper, J. J. Pis, F. Rubiera, C. Pevida, J. Mater. Chem., 2011, 21, 5475-5483.

[73] W. G. Lu, D. Q. Yuan, D. Zhao, C. I. Schilling, O. Plietzsch, T. Muller, S. Brase, J. Guenther, J. Blumel, R. Krishna, Z. Li, H. Zhou, Chem. Mater., 2010, 22, 5964-5972.

[74] W. G. Lu, D. Q. Yuan, J. Sculley, D. Zhao, R. Krishna, H. C. Zhou, J. Am. Chem. Soc., 2011, 133, 18126-18129.

[75] T. Ben, H. Ren, S. Ma, D. Cao, J. Lan, X. Jing, W. Wang, J. Xu, F. Deng, J. M. Simmons, S. Qiu, G. Zhu, Angew. Chem. Int. Ed., 2009, 48, 9457-9460.

[76] M. Vallet-Regi, A. Rámila, R. P. D. Real, Pérez-Pariente, Chem. Mater., 2001, 13, 308-311.

[77] P. Horcajada, T. Chalati, C. Serre, B. Gillet, C. Sebrie, T. Baati, J. F. Eubank, D. Heurtaux, P. Clavette, C. Kreuz, J. S. Chang, Y. K. Hwang, V. Marsaud, P. N. Bories, L. C. Cynober, S. Gil, G. Fery, P. Couvreur, R. Gref, Nat. Mater., 2010, 9, 172-178.

[78] A. C. Mckinlay, R. E. Morris, P. Horcajada, G. Férey, R. Gref, P. Couvreur, C. Serre, Angew. Chem., 2010, 49, 6260-6266.

[79] J. He, Y. He, Y. Fan, B. Zhang, Y. Du, J. Wang, P. Xu, Carbon, 2017, 124, 630-636.

[80] K. P. Song, Z. J. Zou, D. L. Wang, B. Tan, J. Y. Wang, J. Chen, T. Li, J. Phys. Chem. C, 2016, 120, 2187-2197.

[81] H. Cheng, X. L. Feng, D. L. Wang, M. Xu, K. Pandiselvi, J. Y. Wang, Z. J. Zou, T. Li, Electrochim. Acta, 2015, 180, 564-573.

[82] E. C. Hao, W. Liu, S. Liu, Y. Zhang, H. L. Wang, S. G. Chen, F. L. Cheng, S. P. Zhao, H. Z. Yang, J. Mater. Chem. A, 2017, 5, 2204-2214.

[83] H. J. Peng, G. X. Hao, Z. H. Chu, Y. W. Lin, X. M. Lin, Y. P. Cai, RSC Adv., 2017, 7, 34104-34109.

[84] Z. J. Zou, H. Cheng, J. Y. Wang, X. J. Han, Chin. J. Catal., 2015, 36, 414-424.

[85] J. Chen, X. C. Xu, T. Li, K. Pandiselvi, J. Y. Wang, Sci. Rep., 2016, 6, 37318.

[86] Z. L. Xu, C. S. Zhuang, Z. J. Zou, J. Y. Wang, X. C. Xu, T. Y. Peng, Nano Res, 2017, 7, 2193-2209.

[87] K. Pandiselvi, H. F. Fang, X. B. Huang, J. Y. Wang, X. C. Xu, T. Li, J. Hazard. Mater., 2016, 314, 67-77.

[88] Y. Sohn, W. X. Huang, F. Taghipour, Appl. Surf. Sci., 2017, 396, 1696-1711.

[89] Y. F. Ji, Y. Luo, ACS Catal., 2016, 6, 2018-2025.

[90] W. K. Wang, D. F. Xu, B. Cheng, J. G. Yu, C. J. Jiang, J. Mater. Chem. A, 2017, 5, 5020-5029.

[91] S. N. Habisreutinger, L. Schmidt-Mende, J. K. Stolarczyk, Angew. Chem. Int. Ed., 2013, 52, 7372-7408.

[92] Q. J. Xiang, B. Cheng, J. G. Yu, Angew. Chem. Int. Ed., 2015, 54, 11350-11366.

[93] P. Li, Y. Zhou, Z. Y. Zhao, Q. F. Xu, X. Y. Wang, M. Xiao, Z. G. Zou, J. Am. Chem. Soc., 2015, 137, 9547-9550.

[94] S. Q. Liu, Z. R. Tang, Y. G. Sun, J. C. Colmenares, Y. J. Xu, Chem. Soc. Rev., 2015, 44, 5053-5075.

[95] S. Neatu, J. Maciá-Agulló, P. Concepcion, H. Garcia, J. Am. Chem. Soc., 2014, 136, 15969-15976.

[96] Y. X. Pan, Y. You, S. Xin, Y. T. Li, G. Fu, Z. Cui, Y. L. Men, F. F. Cao, S. H. Yu, J. B. Goodenough, J. Am. Chem. Soc., 2017, 139, 4123-4129.

[97] J. Low, B. Cheng, J. G. Yu, M. Jaroniec, Energy Storage Mater., 2016, 3, 24-35.

[98] M. L. Li, L. X. Zhang, X. Q. Fan, Y. J. Zhou, M. Y. Wu, J. L. Shi, J. Ma- ter. Chem. A, 2015, 3, 5189-5196.

[99] J. G. Yu, J. Jin, B. Cheng, M. Jaroniec, J. Mater. Chem. A, 2014, 2, 3407-3416.

[100] L. Zhang, Y. X. Peng, J. Zhang, L. Chen, X. J. Meng, F. S. Xiao, Chin. J. Catal., 2016, 37, 800-809.

[101] M. Anpo, H. Yamashita, K. Ikeue, Y. Fujii, S. G. Zhang, Y. Ichihashia, D. R. Park, Y. Suzuki, K. Koyano, T. Tatsumi, Catal. Today, 1998, 44, 327-332.

[102] M. Anpo, H. Yamashita, Y. Ichihashi, Y. Fujii, M. Honda, J. Phys. Chem. B, 1997,101, 2632-2636.

[103] K. Ikeue, A. Hiromi Yamashita, M. Anpo, T. Takewaki, J. Phys. Chem. B, 2001, 105, 8350-8355.

[104] V. N. Salomone, J. M. Meichtry, M. I. Litter, Chem. Eng. J., 2015, 270, 28-35.

[105] C. S. Lima, K. A. Batista, A. G. Rodríguez, J. R. Souza, F. Fernandes, Solar Energy, 2015, 114, 105-113.

[106] S. K. Kansal, M. Singh, D. Sud, J. Hazard. Mater., 2007, 141, 581-590.

[107] Y. Shioya, K. Ikeue, M. Ogawa, M. Anpo, Appl. Catal. A, 2003, 254, 251-259.

[108] J. S. Hwang, J. S. Chang, S. E. Park, K. Ikeue, M. Anpo, Top. Catal., 2005, 35, 311-319.

[109] M. J. López-Muñoz, R. van Grieken, J. Aguado, J. Marugán, Catal. Today, 2005, 101, 307-314.

[110] C. J. Lin, Y. H. Liou, S. Y. Chen, M. C. Tsai, Sustainable Environ. Res., 2012, 22, 167-172.

[111] Y. Li, W. N. Wang, Z. L. Zhan, M. H. Woo, C. Y. Wu, P. Biswas, Appl. Catal. B, 2010, 100, 386-392.

[112] X. K. Li, W. Li, Z. J. Zhuang, Y. S. Zhong, Q. Li, L. Y. Wang, J. Phys. Chem. C, 2012, 116, 16047-16053.

[113] D. S. Sun, Y. H. Gao, J. L. Fu, X. C. Zeng, Z. N. Chen, Z. H. Li, Chem. Commun., 2015, 51, 2645-2648.

[114] J. N. Qin, S. B. Wang, X. C. Wang, Appl. Catal. B, 2017, 209, 476-482.

[115] L. J. Shen, S. J. Liang, W. M. Wu, R. W. Liang, L. J. Wu, J. Mater. Chem. A, 2013, 1, 11473-11482.

[116] L. J. Shen, W. M. Wu, R. W. Liang, R. Lin, L. Wu, Nanoscale, 2013, 5, 9374-9382.

[117] J. L. Long, S. B. Wang, Z. X. Ding, S. C. Wang, Y. G. Zhou, L. Huang, X. X. Wang, Chem. Commun., 2012, 48, 11656-11658.

[118] S. S. Yan, S. X. Ouyang, H. Xu, M. Zhao, X. Zhang, J. H. Ye, J. Mater. Chem. A, 2016, 4, 15126-15133.

[119] Y. Su, Z. Zhang, H. Liu, Y. Wang, Appl. Catal. B, 2017, 200, 448-457.

[120] S. W. Liu, F. Chen, S. T. Li, X. X. Peng, Y. Xiong, Appl. Catal. B, 2017, 211, 1-10.

[121] L. Shi, T. Wang, H. B. Zhang, K. Chang, J. H. Ye, Adv. Funct. Mater., 2015, 25, 5360-5367.

[122] K. M. Choi, D. Kim, B. Rungtaweevoranit, C. A. Trickett, J. T. O. Barmanbek, A. S. Alshammari, P. Yang, O. M. Yaghi, J. Am. Chem. Soc., 2017, 139, 356-362.

[123] H. B. Zhang, J. Wei, J. C. Dong, G. G. Liu, L. Shi, P. F. An, G. X. Zhao, J. T. Kong, X. J. Wang, X. G. Meng, J. Zhang, J. H. Ye, Angew. Chem. Int. Ed., 2016, 55, 14310-14314.

[124] S. Kandambeth, A. Mallick, B. Lukose, M. V. Mane, T. Heine, R. Banerjee, J. Am. Chem. Soc., 2012, 134, 19524-19527.

[125] A. Patra, J. M. Koenen, U. Scherf, Chem. Commun., 2011, 47, 9612-9614.

[126] S. Wan, J. Guo, J. Kim, H. Ihee, D. Jiang, Angew. Chem. Int. Ed., 2009, 48, 5439-5442.

[127] K. Schwinghammer, B. Tuffy, M. B. Mesch, E. Wirnhier, C. Martineau, F. Taulelle, W. Schnick, J. Senker, B. V. Lotsch, Angew. Chem. 
Int. Ed., 2013, 52, 2435-2439.

[128] L. Stegbauer, K. Schwinghammer, B. V. Lotsch, Chem. Sci., 2014, 5, 2789-2793.

[129] J. Thote, H. B. Aiyappa, A. Deshpande, D. Diaz Diaz, S. Kurungot, R. Banerjee, Chem. Eur. J., 2014, 20, 15961-15965.

[130] L. W. Li, Z. X. Cai, Q. H. Wu, W. Y. Lo, N. Zhang, L. X. Chen, L. Yu, J. Am. Chem. Soc., 2016, 138, 7681-786.

[131] R. S. Sprick, J. X. Jiang, B. Bonillo, S. Ren, T. Ratvijitvech, P. Guiglion, M. A. Zwijnenburg, D. J. Adams, A. I. Cooper, J. Am. Chem. Soc., 2015, 137, 3265-3270.

[132] J X. Low, B. Cheng, J. G. Yu, Appl. Surf. Sci., 2017, 392, 658-686.

[133] L. Yuan, Y. Xu, Appl. Surf. Sci., 2015, 342, 154-167.

[134] M. Tahir, B. Tahir, N. A. Saidina Amin, H. Alias, Appl. Surf. Sci.,
2016, 389, 46-55.

[135] X. G. Meng, S. X. Ouyang, T. Kako, P. Li, Q. Yu, T. Wang, J. H. Ye, Chem. Commun., 2014, 50, 11517-11519.

[136] L. J. Liu, C. Y. Zhao, H. L. Zhao, D. Pitts, Y. Li, Chem. Commun., 2013, 49, 3664-3666.

[137] S. W. Cao, Y. Li, B. C. Zhu, M. Jaroniec, J. G. Yu, J. Catal., 2017, 349, 208-217.

[138] M. S. Akple, J. X. Low, Z. Y. Qin, S. Wageh, A. A. Al-Ghamdi, J. G. Yu, S. W. Liu, Chin. J. Catal., 2015, 36, 2127-2134.

[139] Z. Q. He, J. T. Tang, J. Shen, J. M. Chen, S. Song, Appl. Surf. Sci., 2016, 364, 416-427.

[140] K. Li, B. S. Peng, J. P. Jin, L. Zan, T. Y. Peng, Appl. Catal. B, 2017, 203, 910-916.

\title{
多孔材料的二氧化碳吸附与光催化转化研究进展
}

\author{
马亚娟, 王泽美, 徐晓峰, 王靖宇* \\ 华中科技大学化学化工学院, 能量转换与存储材料化学教育部重点实验室, 湖北武汉 430074
}

摘要: 太阳能光催化是 $\mathrm{CO}_{2}$ 转化和利用的新兴技术, 直接利用洁净充足的太阳能将自然界富有的 “温室气体” $\mathrm{CO}_{2}$ 转化成化 学燃料, 不仅有利于消除大气温室效应, 而且能缓解能源短缺问题, 因而成为人们研究的一个重要方向. 但目前 $\mathrm{CO}_{2}$ 的吸附 和转换效率还很低, 这是太阳能光催化 $\mathrm{CO}_{2}$ 资源化的最大障碍. 高性能光催化剂的设计和合成是这项技术的关键. 针对 $\mathrm{CO}_{2}$ 光还原反应的特异性, 理想的光催化材料应该具有以下功能: 强的 $\mathrm{CO}_{2}$ 吸附能力和高的光催化活性. 将光催化剂与对 $\mathrm{CO}_{2}$ 具有高吸附性的多孔材料结合, 就可以将 $\mathrm{CO}_{2}$ 吸附并富集在吸附剂周围的光催化剂表面上以进行催化转化, 因此基于 高效多孔吸附材料构筑光催化体系成为光催化转化 $\mathrm{CO}_{2}$ 的重要研究方向之一.

$\mathrm{CO}_{2}$ 的循环利用包括吸附和转化两方面, 高吸附量的多孔材料是获得 $\mathrm{CO}_{2}$ 高转化效率的前提. 本文首先以多孔材料结 构参数及性能指标为主线, 对无机多孔材料、金属有机框架材料及微孔有机聚合物材料的研究进展及应用前景进行了评 述. 通过对多孔材料的改性和新型多孔材料的开发, $\mathrm{CO}_{2}$ 的吸附能力得到一定的提升, 但是仅仅依靠多孔材料的吸附分离, 不能实现 $\mathrm{CO}_{2}$ 中的碳资源循环. 在此基础上, 本文重点评述了多孔光催化材料在 $\mathrm{CO}_{2}$ 光催化转化中的最新研究进展. 采用 多孔材料与光催化剂结合, 可增加材料的比表面积, 在界面处暴露更多的活性位点, 有利于光催化 $\mathrm{CO}_{2}$ 转化的进行; 同时, 通过孔结构和基团调控, 可以调控光催化剂的反应活性和产物选择性. 特别是金属有机框架材料与微孔有机聚合物材料, 改变构建单元的官能团和制备技术还可以实现光谱响应范围的调控, 提高太阳光的利用率. 大量文献对比发现, 引入较高 $\mathrm{CO}_{2}$ 吸附效率的多孔材料构建光催化体系, $\mathrm{CO}_{2}$ 光催化转化的效率及产物选择性显著提高.

最后, 本文对多孔材料在 $\mathrm{CO}_{2}$ 光催化转化领域的研究现状与亟待解决的问题进行了剖析, 提出了下一步可能的研究方 向: (1) 提高多孔材料自身的稳定性如耐水性能与光/热稳定性; (2) 发展光催化材料在多孔载体的微观组装方法, 不影响 $\mathrm{CO}_{2}$ 吸附效率的前提下提高光催化活性; (3) 深入研究多孔光催化材料内部与表面的 $\mathrm{CO}_{2}$ 转化机理, 为进一步提高吸附与转 化效率提供理论指导.

关键词: 多孔材料; 纳米复合材料; 二氧化碳吸附; 光催化; 二氧化碳转化

收稿日期: 2017-10-11. 接受日期: 2017-10-31. 出版日期: 2017-12-05.

*通讯联系人. 电话: (027)87543032; 传真: (027)87543632; 电子信箱: jingyu.wang@163.com

基金来源：国家自然科学基金(21771070, 21571071).

本文的全文电子版由Elsevier出版社在ScienceDirect上出版(http://www.sciencedirect.com/science/journal/18722067). 